\title{
Differentiation in morphology and electrical signalling in four species of para- and sympatric Marcusenius (Teleostei: Mormyridae) from Côte d'Ivoire, West Africa
}

\author{
Bernd Kramer* \\ Zoological Institute, University of Regensburg, Regensburg, Germany \\ (Received 22 December 2012; final version received 3 April 2013)
}

\begin{abstract}
Marcusenius Gill, 1862 species were sampled from the Bandama River and the Comoé River in Côte d'Ivoire, West Africa. Marcusenius gracilis sp. nov. was differentiated from M. senegalensis (Steindachner, 1870), Marcusenius ussheri (Günther, 1867) and M. furcidens (Pellegrin, 1920) in electric organ discharges (EOD), and morphologically from all other West African congeners. Principal component analysis showed significant morphological differentiation among the four Ivorian species. Principal component 1 was loaded most strongly by characters affecting swimming power and manoeuvrability. The morphologically most similar pair, M. furcidens and M. gracilis sp. nov., are distinguished by their EOD waveforms and a sexual dimorphism in the anal fin base in the latter not present in the former. M. ussheri is distinguished by a sexual dimorphism in its EOD waveform not observed in the other three species. This system is an opportunity to study how far the fine-tuning of character displacement among syntopic species can go.
\end{abstract}

Keywords: electric fish; Marcusenius sp.; differentiation; electric organ discharges; morphometrics; systematic; speciation

\section{Introduction}

The African fish genus Marcusenius Gill, 1862 is one of the largest within the family of Mormyridae or snoutfish, the African weakly electric fishes. After the major revision of the genus by Taverne (1971a, 1971b), Marcusenius now comprises about 37 species, nine of which occur in West Africa and three in Côte d'Ivoire (Figure 1). In recent years, the study of the systematics of West African Marcusenius species has advanced rapidly, thanks to the studies by Jégu and Lévêque (1984), Bigorne (1990), Bigorne and Paugy (1990), Boden et al. (1997) and the molecular genetics study by Agnèse and Bigorne (1992). The West African Marcusenius species have been aptly characterized and a key constructed by Bigorne (1990, 2003) in Paugy, Lévêque and Teugels (2003).

Marcusenius species are widespread in Africa and members of this genus have been the object of additional systematic studies (such as Kramer et al. 2007), ecological studies (such as Planquette \& Lemasson 1975; Hyslop 1986; Adebisi 1987; Bailey 1989), physiologically orientated studies regarding electrical signalling (such as Toerring \& Serrier 1978; Graff 1989) and ontogenetic developmental studies (Werneyer \& Kramer 2006).

*Email: bernd.kramer@biologie.uni-regensburg.de 


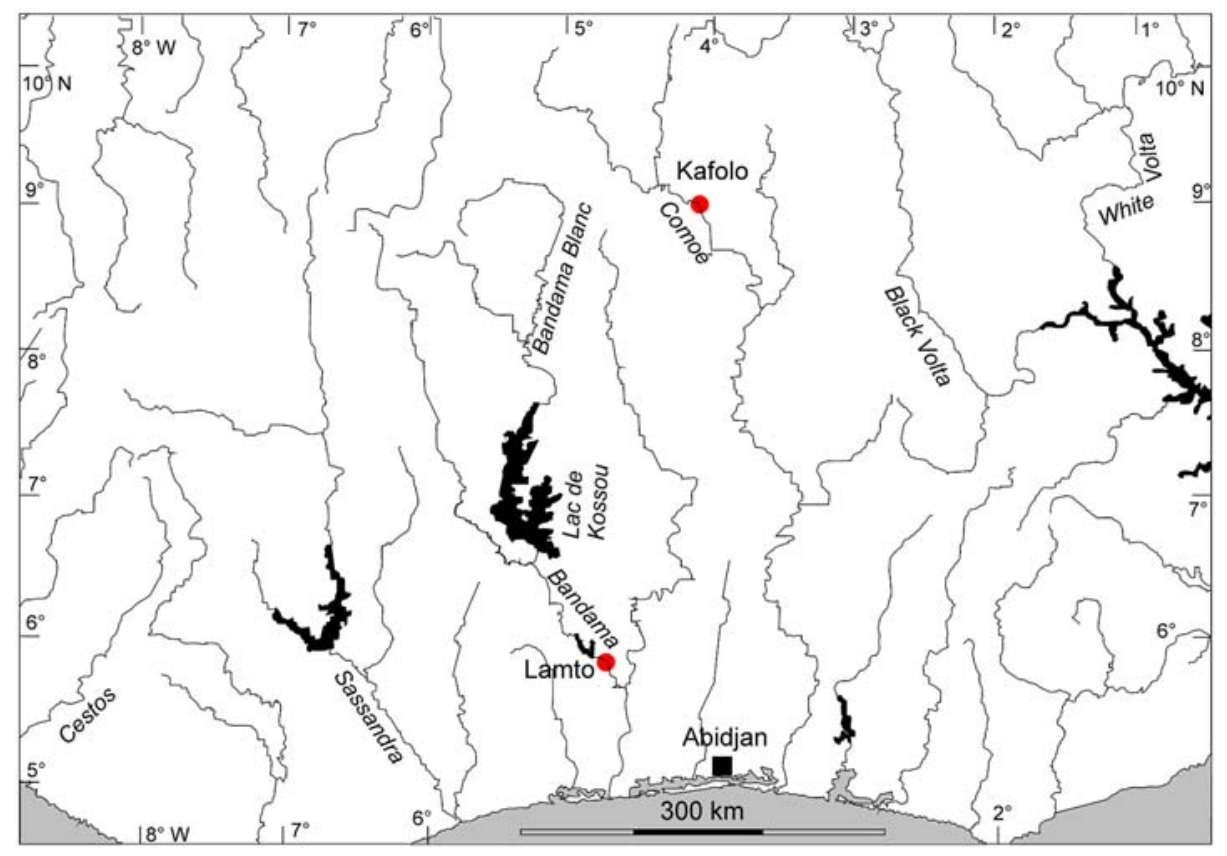

Figure 1. Map of sampling locations in Côte d'Ivoire, West Africa. Lamto designates the Station d'Écologie de Lamto on the Bandama River, and Kafolo is the location of the Campement de Recherche sur les Mouches Tsétsé on the Comoé River where it forms the international border with Burkina Faso.

Behavioural studies of electrocommunication are those of Moller (1976), Scheffel and Kramer (1997) and Werneyer and Kramer (2002, 2005). An electrosensory/ecological study regarding detection by electroreceptive predators is that of Hanika and Kramer $(1999,2000)$. Sexual selection studies focusing on the electrosense are those by Hanika and Kramer (2005, 2008), Machnik and Kramer (2008a, 2008b, 2011) and Machnik et al. (2010). Species differentiation in acoustic signalling among Marcusenius species was demonstrated by Lamml and Kramer (2007).

Notwithstanding the interest the genus has received from systematists and neuroethologists, the biology, ecology and behaviour of many species is only poorly known or not known at all, and it was not always clear which species was used, especially when commercially imported fish were studied the origins of which are usually vague. Field studies on West African mormyrids are rare. Studies combining morphology with EOD analysis are the ones by Crawford and Hopkins (1989) and Roberts (1989) who together described a new Mormyrus species for Côte d'Ivoire, and Kramer (2013) also on Mormyrus species. Moritz et al. (2008) studied EODs of several mormyrid species and genera from the Upper Volta system, among them Marcusenius senegalensis, that were not accompanied by morphological or genetic studies.

The present study provides more details on morphology, electrical signalling and differentiation than was available about the three Marcusenius species known to occur in Côte d'Ivoire, that is, M. senegalensis (Steindachner, 1870), M. ussheri (Günther, 1867) and Marcusenius furcidens (Pellegrin, 1920) (Figure 2). The original descriptions barely surpass one page per species, are written in a telegraphic style and give precious little or even no information as to sampling locations, specimen numbers, size range, 

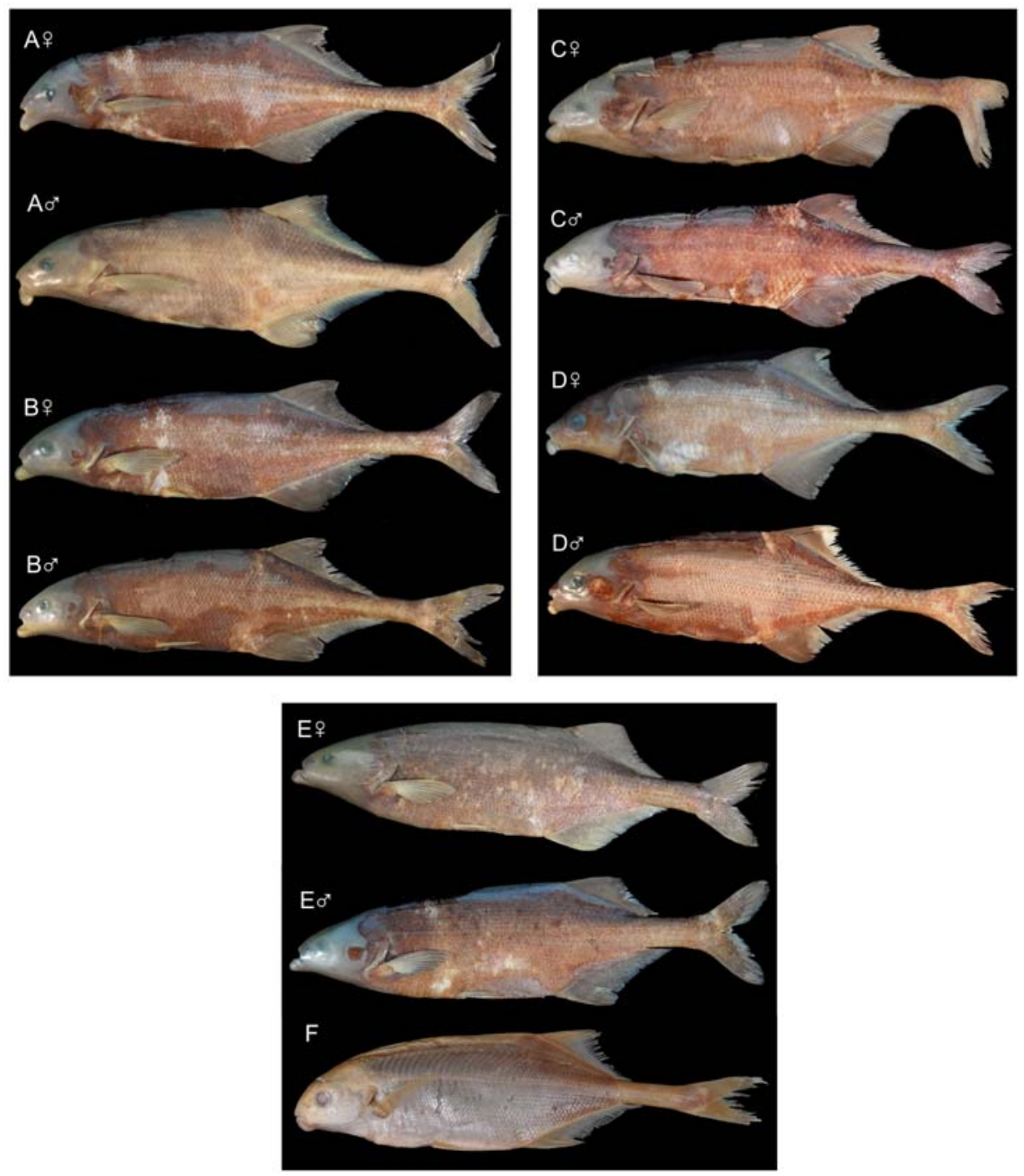

Figure 2. Photos of four Ivorian Marcusenius species, sex confirmed by gonad histology, and of M. mento. (A) M. furcidens from Comoé River; female, ZSM 42214 (field no. Kaf002, SL $20.2 \mathrm{~cm}$ ), with eggs stage II; male, ZSM 42211 (field no. Kaf034, SL $21.4 \mathrm{~cm}$ ). (B) M. gracilis sp. nov. from Comoé River; female, ZSM 42220 (field no. Kaf051, SL $19.4 \mathrm{~cm}$ ), with eggs stages I-IV; male, ZSM 42204, holotype (field no. 201/45/46/48, SL $22.1 \mathrm{~cm}$ ). (C) M. ussheri from Bandama River; female, ZSM 42208 (field no. LAM42, SL $15.6 \mathrm{~cm}$ ), with eggs stages I-IV; male, ZSM 42209 (field no. LAM22, SL $20.4 \mathrm{~cm}$ ). (D) M. furcidens from Bandama River; female, ZSM 42218 (field no. LAM16, SL $17.2 \mathrm{~cm}$ ), with eggs stage IV; male, ZSM 42218 (field no. LAM15, SL 16.6 cm). (E) M. senegalensis from Comoé River; female, ZSM 42193 (field no. Kaf011, SL 16.6 cm), with eggs stages I-II; male, ZSM 42191 (field no. Kaf052, SL $17.2 \mathrm{~cm}$ ). (F) M. mento, BMNH 1881.7.20, holotype, Gabon, SL $16.3 \mathrm{~cm}$.

collection accession numbers, distinction from closest relatives or syntopous species and ecology. A new species was discovered during the course of this study. 


\section{Materials and methods}

The methods followed were mostly those detailed in Kramer (2013) where additional information may be found. Particular to this report are:

\section{Morphology}

Fish were sampled from the Comoé River where it forms the border between northern Côte d'Ivoire and Burkina Faso at a small place called Kafolo, at the Campement de Recherche sur les Mouches Tsétsé, $9^{\circ} 36^{\prime} \mathrm{N}, 4^{\circ} 19^{\prime} \mathrm{W}$, and at the Station d'Écologie de Lamto, $6^{\circ} 11^{\prime} \mathrm{N}, 5^{\circ} 0^{\prime} \mathrm{W}$, on the Bandama River in central Côte d'Ivoire (Figure 1).

Sixteen anatomical measurements (Figure 3) and four counts were performed on 70 specimens from the two origins in Côte d'Ivoire. PDL= predorsal length (distance from the tip of the snout to the dorsal fin origin). PAL= distance tip of snout (= upper lip) to anal fin origin. $\mathrm{LD}=$ dorsal fin length. $\mathrm{LA}=$ anal fin length. $\mathrm{pD}=$ distance dorsal fin origin to end of caudal peduncle. $\mathrm{CPL}=$ length of caudal peduncle (end of anal fin base to midbase of the caudal fin). $\mathrm{CPD}=$ depth of caudal peduncle (the least vertical distance across the caudal peduncle). LSo=length of snout (distance from the tip of the snout to the posterior orbital rim of the eye. LSc=length of snout (distance from the tip of the snout to the centre of the eye). HL=head length (distance from the tip of the snout to the furthest bony edge of the operculum. $\mathrm{Na}=$ distance between the pair of nares on one side (from centre to centre). $\mathrm{OD}=$ eye diameter defined by the orbital rims. $\mathrm{LPF}=$ length of the pectoral fins. $\mathrm{PPF}=$ distance from the origin of the pelvic fin to the origin of the anal fin (some specimens). SL= standard length (distance between the tip of the snout to the midbase of the caudal fin). $\mathrm{BD}=$ body depth (the greatest vertical distance across the body). $\mathrm{nD}=$ number of dorsal fin rays. $\mathrm{nA}=$ number of anal fin rays. $\mathrm{SPc}=$ number of scales around the caudal peduncle. SLS = number of scales in a linear series along the lateral line row, as detailed in Skelton (2001, p. 67). SLS $=$ range of accuracy \pm 2 counts. Measurements were all point-to-point; no projections into other planes were used.

The sex of M. ussheri, M. senegalensis and M. gracilis sp. nov. specimens was recognized by the presence or absence of a kink in their anal fin base which is present in

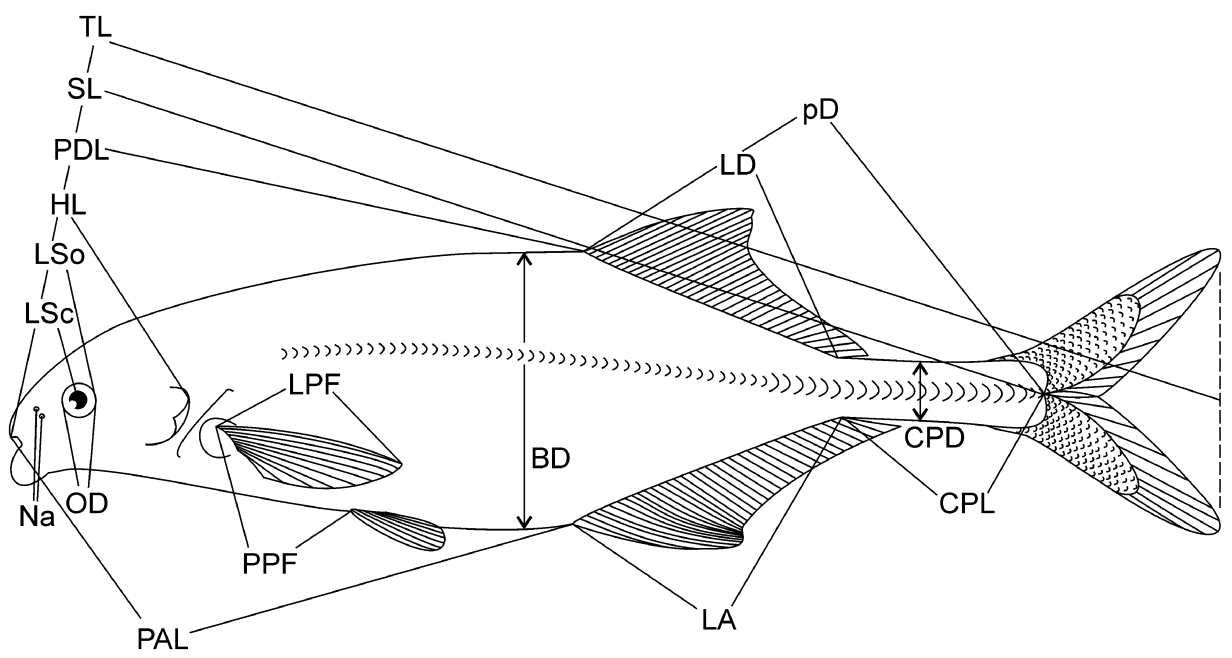

Figure 3. Morphological measures used in the present study, explained on an M. furcidens. For abbreviations, see Material and methods. 
the males of many mormyrid species; in addition, most specimens' gonads were also studied histologically and the stage of egg development determined. Gonad histology was the only means to determine the sex in the specimens of M. furcidens, as the kink character was not present in the males of this species. The gonads were dissected and embedded in paraffin. Sections of $7 \mu \mathrm{m}$ were stained following the Azan protocol (Mulisch \& Welsch 2010; for details, see Kramer 1997b). The classification of ovary development stages (I -VI) followed Takashima and Hibiya (1995).

Abbreviations used to represent institutions and collections cited follow Leviton et al. (1985) and Fricke and Eschmeyer (2012). Specimens examined were identified using dichotomous keys in Lévêque and Paugy (1984), Lévêque et al. (1990) and Paugy et al. (2003) which are considered effective for fish populations occurring in West Africa.

\section{Electric organ discharges}

Electric organ discharges (EODs) were recorded in the field immediately after capture of fish. Measurements were taken in a 37 litre plastic aquarium filled with water from the river where the fish was collected. Conditions in the aquarium were kept constant throughout the analysis to exclude the possibility that water quality (conductivity and temperature) could affect EOD measurements.

Temperature $\left( \pm 0.1^{\circ} \mathrm{C}\right)$ and water conductivity $\left( \pm 1 \mu \mathrm{S} \mathrm{cm}^{-1}\right)$ were constantly monitored using an electronic apparatus (LF318 Wissenschaftlich-Technische Werkstätten WTW, Germany). Fish were placed between a pair of carbon rod electrodes that were connected to a differential amplifier with a variable gain (up to $\times 10 ; 0.2 \mathrm{~Hz} \ldots$ $100 \mathrm{kHz}$; filter slopes, $-3 \mathrm{~dB}$ per octave; electronics workshop, Biology Department, University of Regensburg). Amplifier output was recorded with a digital storage oscilloscope (specified to at least $20 \mathrm{MHz} / 8$ bit and either 512 or 2048 points per sweep). Data were numerically transferred onto disk via digital interface. Usually four traces per fish were recorded. Except for the first year of the study, 1990, all the field equipments were battery-operated.

Custom-designed computer programs were used for analysis of EODs (programmed using a software package for signal analysis, Famos v6 by imc Company, Berlin). When necessary, EOD duration was normalized to $25^{\circ} \mathrm{C}$ using a Q10 value of 1.5 (Kramer \& Westby 1985) before data analysis, due to the dependency of the mormyrid EOD duration on temperature.

The EOD waveform variables can be defined as follows (Figure 4): Pamp, peak amplitude of head-positive $\mathrm{P}$ phase, measured from baseline to maximum (which was equal to $+1 \mathrm{~V}$ by definition); Namp, head-negative peak amplitude of $\mathrm{N}$ phase, measured from baseline to minimum; Ndur, Pdur, durations of $\mathrm{N}$ and $\mathrm{P}$ phases, respectively; PNsep, separation (or interval) between the peaks of the $\mathrm{P}$ and $\mathrm{N}$ phases; Parea, Narea, areas under the $\mathrm{P}$ and $\mathrm{N}$ phases; EODdur, total EOD duration. Durations in microseconds or milliseconds, as indicated; amplitudes in relative Volts (re: P-phase amplitude $=+1$ ). Area-under-curve measures dimension $(V \times$ microseconds). The start of the initial $\mathrm{P}$ phase and the end of the subsequent $\mathrm{N}$ phase were determined at a threshold level of $+2 \%$ and $-5 \%$ of Pamp, respectively; $\mathrm{P}$ ended and $\mathrm{N}$ started at the zero-crossing between them. The reason why $\mathrm{N}$ ended at $-5 \%$ (rather than at zero-crossing, or at $-2 \%$ ) was that most specimens' EODs, except those of $M$. senegalensis, did not show an appreciable head-positive post-potential, but returned to baseline asymptotically after widely varying times, and the value could not meaningfully be determined due to noise. 


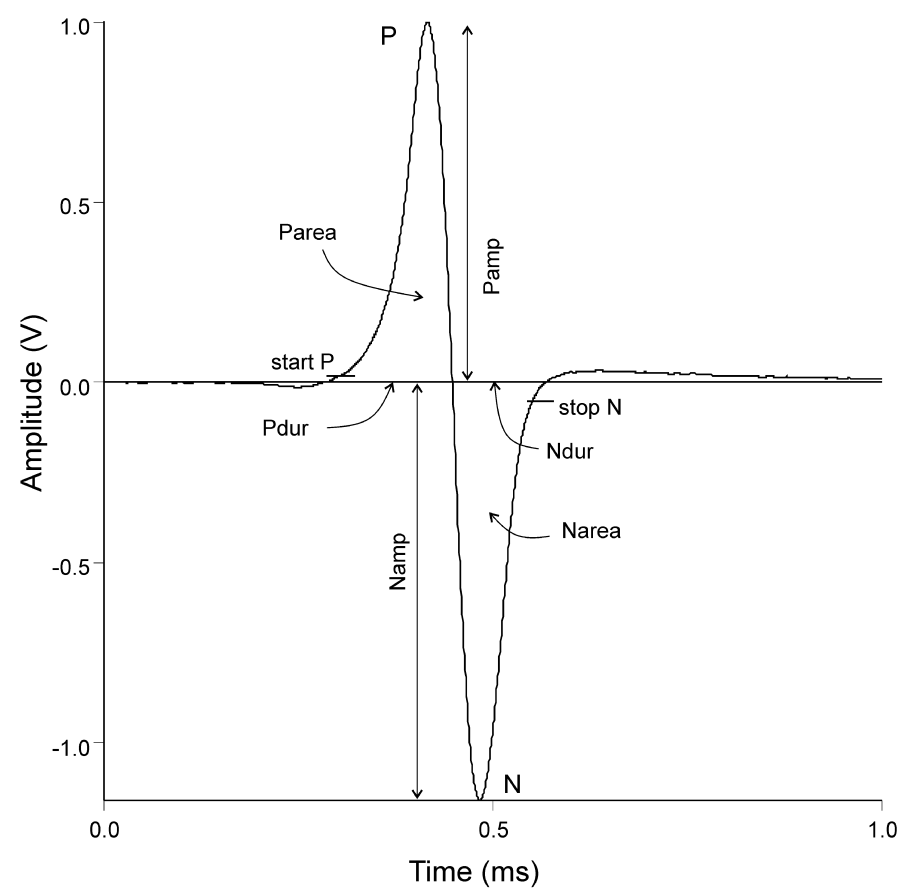

Figure 4. EOD waveform example of an M. senegalensis with baseline superimposed, showing the waveform characters as defined in the present study. Prior to analysis an EOD was normalized in amplitude by its $\mathrm{P}$ phase set equal to 1 Volt from baseline. An EOD started where it crossed the $+2 \%$ level of $\mathrm{P}$ phase amplitude ("start P"), it ended where it crossed the $-5 \%$ level of P amplitude ("stop N").

A fast Fourier transform (FFT) routine provided by Famos performed amplitude spectra of single EOD pulses. Analogue-to-Digital (A/D) sampling rates were reduced to between 100 and $125 \mathrm{kHz}$ to obtain a better low-frequency resolution. The number of data points for FFT analysis was usually $2^{17}$, obtained by extending baseline with zeros such that a single EOD per record was centred (Davis \& Hersh 1980; Keuper, 1988; Bracewell 2000). Frequency resolution was about $1 \mathrm{~Hz}$. The peak power frequency (PPF in $\mathrm{Hz}$ ) and the frequencies at -10 and $-20 \mathrm{~dB}$ attenuations re: PPF were determined from these spectra.

Subsequent to EOD recording, fish were killed with an overdose of the anaesthetic MS222. SL was measured with vernier callipers prior to fixing the specimen in $10 \%$ formalin for morphological studies.

\section{Statistics}

Univariate ANOVA and multivariate analysis of variance (MANOVA) were used to test for significant differences between samples. Means are given with \pm standard errors, medians with \pm semi-interquartiles. Principal component analyses (PCA) on correlations among anatomical characters were used to test differentiation among samples, because it does not require a priori assumptions about taxonomic groups. The component loadings, i.e. the principal component structure, were useful for interpreting the principal components in terms of the anatomical characters (McGarigal et al. 2000). Tabachnick and Fidell (2007) interpret the significance of component loadings as follows: these 
authors recognise five levels of significance: loadings $>0.32$ or $<-0.32$ are poor, $>0.45$ or $<-0.45$ are fair, $>0.55$ or $<-0.55$ are good, $>0.63$ or $<-0.63$ are very good and $>0.71$ or $<-0.71$ are excellent. These benchmarks account for 10, 20, 30, 40 and 50\% of the variance in the component. Discriminant analyses (DA) found the best separation among the specimens from different species in multidimensional space, using JMP v. 9 software (SAS Institute, Cary, NC, USA, 2007). The best result was obtained by stepwise variable selection, as measured by the smallest -2LogLikelihood (i.e. minus two times the natural $\log$ of the likelihood function evaluated at the best-fit parameter estimates).

\section{Ecology}

This presentation follows the one given in Kramer (in press). The Bandama River of about $950 \mathrm{~km}$ length (http://www.fao.org/docrep/005/V4110E/V4110E03.htm) is an independent, permanent river discharging into the Atlantic Ocean. Arising in the north of Côte d'Ivoire, it runs through tropical rain forest in a southerly direction. Its water volume varies considerably throughout the year, but the river has not been recorded to run dry. Water level is highest from September to October (UNESCO - Le Bandama à Tiassalé, http://fr.wikipedia.org/wiki/Bandama). The Comoé River of about $1100 \mathrm{~km}$ length arises from highlands in Burkina Faso (http://www.rezoivoire.net/cotedivoire/patrimoine/105/le-reseau-hydrographique-ivoirien.html\#.UTx23zdE-x0), also heading to the Atlantic Ocean in a southerly direction. In contrast to the Bandama, the Comoé is an intermittent and irregular river that usually flows only in the months from July to November (GRDC - La Comoé à Agniassué; http://fr.wikipedia.org/wiki/Como\%C3\% A9_\%28fleuve\%29). For most of the year the Comoé is a series of pools ("mares") some of which are quite deep, permitting hippopotami to dive. The Comoé crosses a typical dry Sahel zone with scattered small trees. The Comoé is fringed by a narrow gallery forest that, were present, is only a few metres wide. The river banks are high and steep, and difficult to climb in times of rain. Bush vegetation on rocky islands in the river bed is strongly bent downstream, another sign of violent current when the river is high. The length of a similar intermittent river, the Baoulé in Mali, is estimated to comprise $10 \%$ in the dry season, with the lower reaches being completely dry (Paugy 2002). Water temperature and conductivity rise to $35^{\circ} \mathrm{C}$ and $120 \mu \mathrm{S} / \mathrm{cm}$, respectively, and oxygen levels drop to $2.1-3 \mathrm{mg} / \mathrm{l}$. In times of flow temperature and conductivity fall to $25^{\circ} \mathrm{C}$ and $40 \mu \mathrm{S} / \mathrm{cm}$. Fish reproduction in the Baoulé takes place only during, or shortly before, a period of intense flooding. The period of actual flow lasts only four to five months, from July to November. Much of Paugy's (2002) report on the Baoulé also applies to the Comoé River.

\section{Results}

\section{Morphology}

Bigorne (1990) in Lévêque et al. (1990) and Bigorne (2003) in Paugy et al. (2003) are the most authoritative references for mormyrids in West Africa. Three Marcusenius species are known for Côte d'Ivoire, including the two rivers sampled in the present study, the Comoé and the Bandama Rivers, and could be identified by morphometrics, using Bigorne's (2003) key. Descriptive morphological data for all Marcusenius samples, split by origin (Bandama or Comoé Rivers) are given in Table 1. Marcusenius furcidens was sampled from both rivers, M. senegalensis only from the Comoé and M. ussheri only 
from the Bandama, although the presence of all three species in both rivers has been reported. However, an additional sample clearly recognizable as a Marcusenius species was recovered from the Comoé River ( $N=17$; Figure 2). It corresponded to none of the three species. Therefore, the sample was compared to all other species known for West Africa.

Bigorne (2003) lists nine Marcusenius species for the whole of West Africa: in addition to those given above, M. abadii (Boulenger, 1901), M. brucii (Boulenger, 1910), M. cyprinoides (Linnaeus, 1758), M. mento (Boulenger, 1890), M. meronai Bigorne et Paugy, 1990 and M. thomasi (Boulenger, 1916). The unknown Marcusenius species has bicuspid (notched) teeth, therefore, M. brucii, M. cyprinoides and M. abadii, all of which have conical teeth (like M. senegalensis) can be excluded. This leaves $M$. thomasi as a possibility for the unknown sample. However, M. thomasi's ratio of dorsal fin length to anal fin length (LD/LA) is too low for this hypothesis: M. thomasi's maximum ratio of 0.7 is considerably lower than the minimum ratio in the unidentified sample $($ mean $=0.844$, minimum 0.792 , maximum $0.898 ; N=17$, Table 1 ). Therefore, the unknown sample is not referable to $M$. thomasi. The next species following the key is $M$. mento, a species with a fragmented West African distribution not including Côte d'Ivoire (the holotype of which is from Gabon; possibly in error: Hopkins et al. 2007, p. 287). M. mento's lateral line scale count, as given in the key, is greater than 75 (76-87). The holotype has 81 lateral line scales (no paratypes existing), whereas the unknown sample's range was 70-77, with a median of 73 (Table 1). A reference work for the Lower Guinean ichthyological province, which includes the Gabon, quotes the range of lateral line scales of M. mento as 79-85 (Table 12.2 in Hopkins et al. 2007). In conclusion, the present unknown sample is not referable to M. mento.

Three species remain in Bigorne's key, M. furcidens, M. ussheri and M. meronai; the latter is only known from the distant Sierra Leone. The number of dorsal fin rays of the present sample of $M$. furcidens was higher than that of the unknown sample (29-33 vs. 26-30 in the latter; Table 1); Bigorne (2003) gives 29-34 rays for M. furcidens. In addition, the males of the unknown sample exhibited a kink in the anal fin base that was not present in the M. furcidens males (Figure 2). This excludes M. furcidens as a species referable to the unknown sample. The presence of $M$. ussheri is also reported in both river systems studied. The unknown sample of the Comoé does not fit Bigorne's description for $M$. ussheri because the ranges of lateral line scale counts (SLS) are different: $50-65$ in M. ussheri (52-60 in the present sample of $N=16$ ) vs. $70-77$ in the unknown sample. Head length is lower in the unidentified sample (17.3-19.7\% of SL) than in the M. ussheri from our collections (19.1-21.1\% of SL). Caudal peduncle depth was lower in the unidentified sample (CPD is $24.7-31.9 \%$ of CPL compared to $30.1-37 \%$ in M. ussheri and there are additionally other differences (Table 1, Figure 2). In conclusion, morphometrics do not support the hypothesis that the unknown sample is M. ussheri. The last remaining species, M. meronai, is also not the species referable to the unknown sample: the dorsal fin ray counts in M. meronai vary between 21 and 23 in Bigorne's (2003) key vs. 26-30 in the unknown sample from the Comoé River. The range of $M$. meronai's caudal peduncle depth (CPD/CPL ratio) was greater than that the unknown sample $(0.37-0.476$ in the former vs. $0.214-0.266$ in the latter), and exceeds that of all present samples from Côte d'Ivoire except that of M. senegalensis. In conclusion, the unknown sample apparently represents an as yet unknown, new species. It will be referred to as M. gracilis sp. nov. in Systematics.

A MANOVA including all samples showed there was at least one character that differed significantly among the five groups $(p<0.0001$, Table 2). Subsequent ANOVAs 


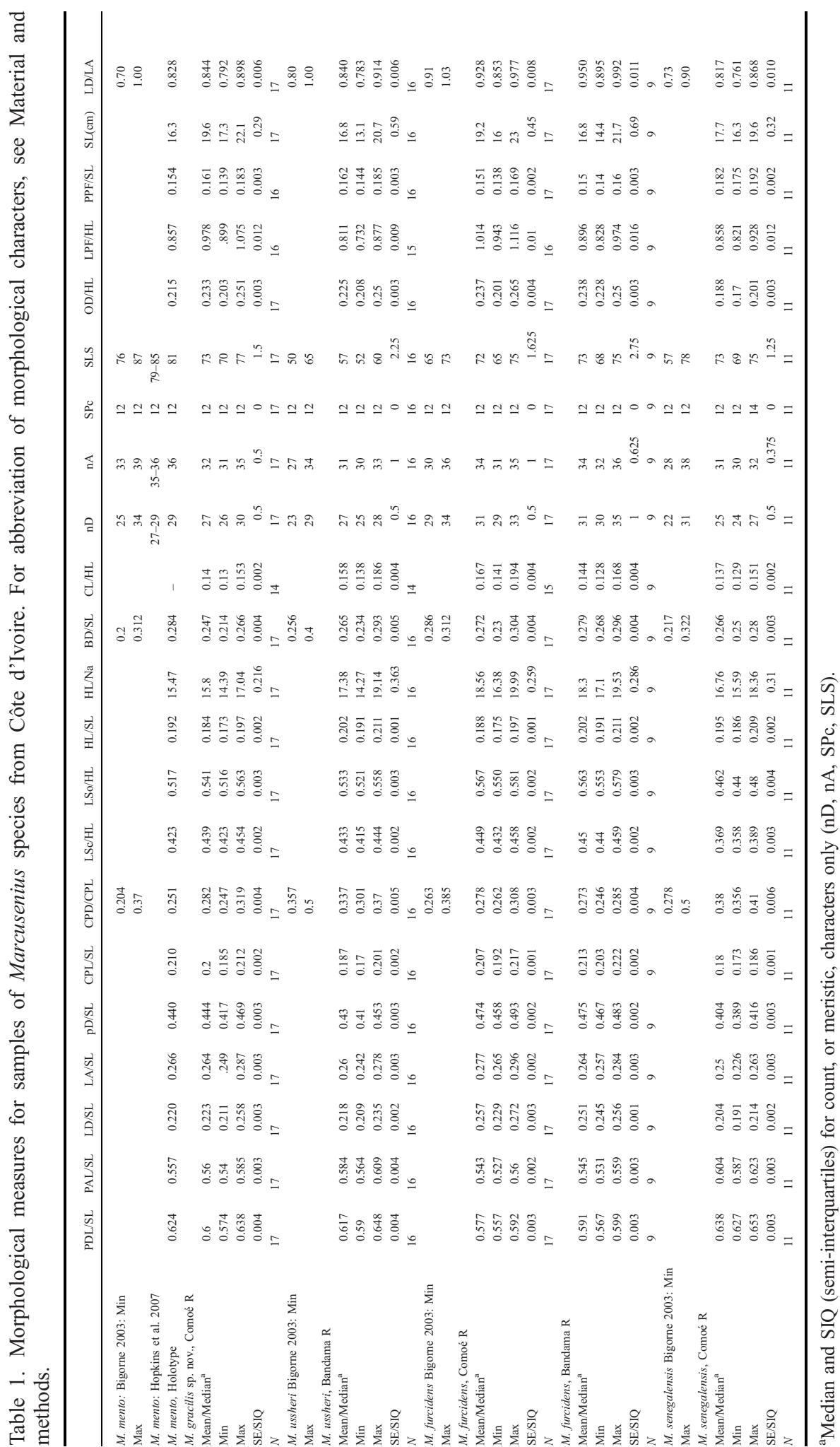




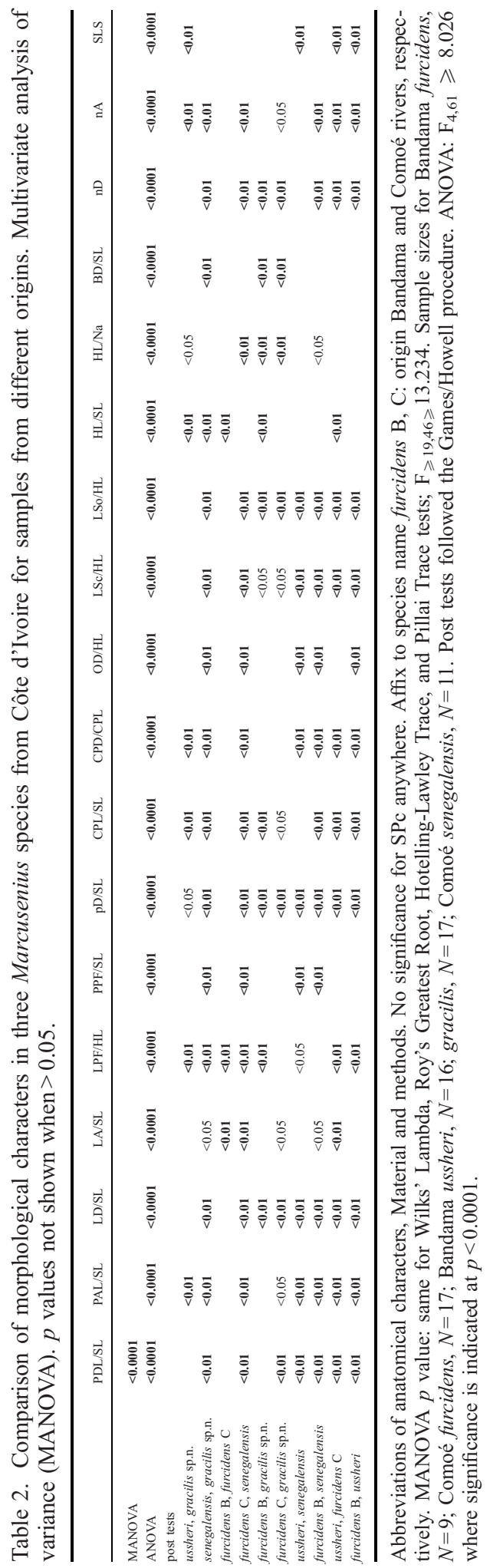


showed that all characters but one contributed to this result (at $p<0.0001$ ). The one character that did not was the number of scales around the caudal peduncle, SPc, which was 12 everywhere and hence uninformative, and not included in Table 2.

Post hoc tests allowed us to identify the pairs of samples between which the differences for individual characters were significant. For example, the $M$. furcidens sample from the Comoé River $(N=17)$ differed from that of the Bandama River $(N=9)$ in three characters (LA, LPF and HL), i.e. there was some geographical differentiation. By contrast, the $M$. ussheri (Bandama, $N=16$ ) and the unknown sample from the Comoé $(M$. gracilis sp. nov.; $N=17)$ differed in seven characters at $p<0.01$ and two additional ones at $p<0.05$, i.e. there was strong differentiation not supporting the assumption of a single species. Syntopic M. furcidens and $M$. gracilis sp. nov. from the Comoé differed in nine characters (plus one at $p<0.05$ ). Pairwise comparisons between syntopic $M$. ussheri and furcidens samples from the Bandama River also yielded clear differentiation: 13 differences at $p<0.01$. M senegalensis was well differentiated from any other group (at least 10 significant differences at $p<0.01$ ).

To explore further the hypothesis of four rather than three species in the present sample of Ivorian Marcusenius species, PCA and DA for correlations seemed appropriate. The first three principal components captured $75.8 \%$ of the variance in the dataset and PCA was hence very successful in reducing the dimensionality (Table 3). PCA showed four clusters of samples: one for M. furcidens with samples from both origins overlapping one another, confirming their close relationship. There were two well-isolated clusters for M. senegalensis and M. ussheri, and a fourth cluster, M. gracilis sp. nov. from the Comoé River (Figure 5). The latter cluster and the one of M. furcidens both held an outlier from the other species. The point for the holotype of M. mento was

Table 3. Principal components analysis on correlations for 19 morphological characters of Marcusenius specimens from Côte d'Ivoire. For abbreviations, see Material and methods.

\begin{tabular}{lcccrcrc}
\hline Eigenvalue & 10.3221 & 2.4836 & 1.6027 & 1.074 & 0.8825 & 0.5662 & 0.5413 \\
Percent & 54.327 & 13.071 & 8.435 & 5.653 & 4.645 & \multicolumn{1}{c}{2.98} & \multicolumn{1}{c}{2.849} \\
Cum percent & 54.327 & 67.398 & 75.833 & 81.486 & 86.131 & 89.111 & \multicolumn{1}{c}{91.96} \\
Component loadings & & & & & & \\
PDL/SL & -0.93628 & 0.1372 & 0.02372 & 0.17494 & 0.06923 & 0.05188 & -0.00998 \\
$\mathrm{PAL} / \mathrm{SL}$ & -0.95464 & 0.14294 & 0.03552 & 0.04424 & -0.02283 & 0.10983 & 0.03718 \\
$\mathrm{LD} / \mathrm{SL}$ & 0.88785 & 0.2485 & 0.25097 & -0.10906 & -0.11093 & 0.01759 & 0.08435 \\
$\mathrm{LA} / \mathrm{SL}$ & 0.77368 & -0.14632 & -0.04687 & -0.43326 & -0.20886 & -0.07042 & 0.2672 \\
$\mathrm{LPF} / \mathrm{HL}$ & 0.67696 & -0.46323 & 0.23642 & 0.10764 & -0.12267 & 0.33236 & 0.07449 \\
$\mathrm{PPF} / \mathrm{SL}$ & -0.79862 & 0.01162 & 0.34033 & 0.27387 & -0.04152 & 0.30074 & 0.0459 \\
$\mathrm{pD} / \mathrm{SL}$ & 0.95296 & 0.11244 & 0.04165 & -0.02371 & 0.00514 & -0.10519 & -0.03789 \\
$\mathrm{CPL} / \mathrm{SL}$ & 0.84073 & -0.0695 & -0.00119 & 0.27864 & 0.18971 & -0.20264 & -0.28224 \\
$\mathrm{CPD} / \mathrm{CPL}$ & -0.89677 & 0.15814 & 0.15846 & -0.21616 & -0.11881 & -0.01188 & 0.17963 \\
$\mathrm{LSc} / \mathrm{HL}$ & 0.79799 & 0.24243 & -0.36128 & 0.12118 & 0.13783 & 0.22238 & -0.03247 \\
$\mathrm{LSo} / \mathrm{HL}$ & 0.86934 & 0.2577 & -0.22539 & 0.09839 & 0.1453 & 0.17399 & 0.00799 \\
$\mathrm{OD} / \mathrm{HL}$ & 0.73386 & 0.16617 & -0.34012 & 0.15093 & 0.19693 & 0.21753 & 0.18067 \\
$\mathrm{HL} / \mathrm{SL}$ & -0.33924 & 0.84438 & -0.0254 & 0.08179 & 0.10174 & -0.26163 & 0.01088 \\
$\mathrm{HL} / \mathrm{Na}$ & 0.33057 & 0.51284 & 0.33362 & -0.41324 & -0.2332 & 0.24204 & -0.43656 \\
$\mathrm{BD} / \mathrm{SL}$ & 0.06566 & 0.75994 & 0.44844 & 0.28599 & 0.04807 & 0.0511 & 0.16971 \\
$\mathrm{nD}$ & 0.85397 & 0.27011 & 0.30885 & 0.00044 & -0.04649 & -0.06243 & 0.01569 \\
$\mathrm{nA}$ & 0.7773 & 0.02836 & 0.36296 & 0.04815 & -0.02073 & -0.11228 & 0.27439 \\
$\mathrm{SPc}$ & -0.2146 & -0.09088 & 0.31747 & -0.48653 & 0.77161 & 0.08438 & 0.03403 \\
$\mathrm{SLS}$ & 0.30464 & -0.56182 & 0.63175 & 0.29139 & 0.10205 & -0.1128 & -0.10144 \\
\hline
\end{tabular}

M. furcidens Comoé River, $N=16 ; M$. furcidens Bandama River, $N=9 ; M$. gracilis sp.nov. Comoé River, $N=15 ; M$. ussheri Bandama River, $N=15 ;$ M. senegalensis Comoé River, $N=11$. 


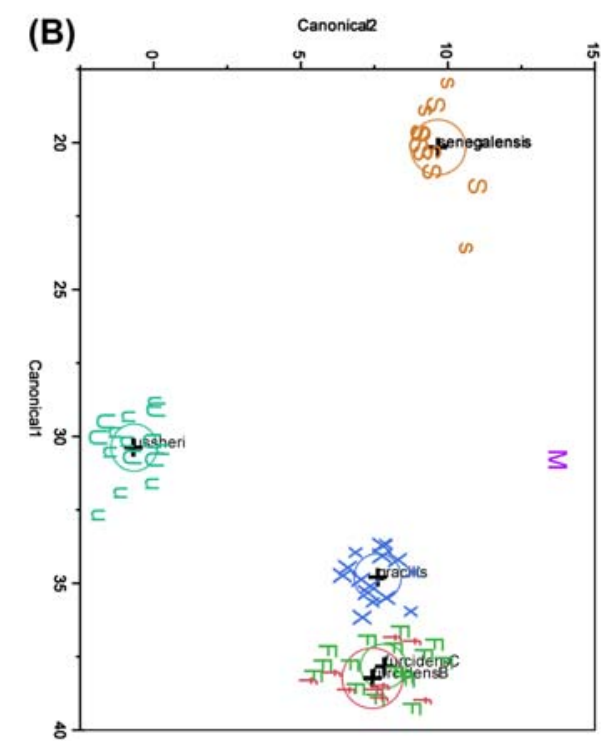

Figure 5. Multivariate analysis on morphology of Marcusenius species in Côte d'Ivoire. (A) Principal components analysis on correlations for 18 morphological characters (i.e. all except SPc). Prin1, Prin2 and Prin3 axes represent the first three principal components. (B) Discriminant analysis showing 95\% confidence circles to contain true mean of group. F symbols, $M$. furcidens (Comoé River, $N=16$ ); f symbols, $M$. furcidens (Bandama River, $N=9$ ); U and u symbols, females and males of $M$. ussheri (Bandama River, $N=15$ ), respectively; $\mathrm{X}$ and $\mathrm{X}$ symbols, females and males of $M$. gracilis sp. nov. (Comoé River, $N=15$ ), respectively; $\mathrm{S}$ and s symbols, females and males of $M$. senegalensis specimens (Comoé River, $N=11$ ), respectively. M symbol, holotype of $M$. mento.

isolated from the other groups which is support for the above conclusion that the species of the unknown group, termed $M$. gracilis sp. nov., is not M. mento.

DA showed the best separation among the five groups. Both M. senegalensis and M. ussheri specimens were located in isolated clusters, whereas the $95 \%$ confidence circles for $M$. furcidens specimens of the two origins were overlapping one another. Separate from the two furcidens clusters but rather close was the one for M. gracilis sp. nov. with its distribution of specimens not overlapping furcidens. Considering also the difference in male anal fin shape (that was not entered into the analysis), there can be no doubt of strong morphological differentiation also between these two species. None of $M$. gracilis sp. nov. specimens were misclassified as one of the other species, and out of 67 specimens included, only one $M$. furcidens from the Bandama River (1.5\%) was misclassified as an $M$. furcidens from the Comoé River, because of a lack of separation of the means. The holotype of $M$. mento $(N=1)$ was excluded from the calculation of confidence circles but its position shown on the graph; it was far off any association with the present samples of Ivorian Marcusenius.

Principal Component 1 (PC1) for the whole data-set was positively loaded by $\mathrm{pD} /$ $\mathrm{SL}, \mathrm{LD} / \mathrm{SL}, \mathrm{LSo} / \mathrm{HL}, \mathrm{nD}, \mathrm{CPL} / \mathrm{SL}, \mathrm{PPF} / \mathrm{SL}, \mathrm{LSc} / \mathrm{HL}, \mathrm{nA}, \mathrm{LA} / \mathrm{SL}, \mathrm{OD} / \mathrm{HL}$ (all "excellent"), LPF/HL ("very good") and HL/Na ("poor"); it was negatively loaded by PAL/ SL, PDL/SL, CPD/CPL, PPF/SL (all "excellent") and HL ("poor"). PC1 thus represents a gradient for enhanced unpaired fins, pectoral fins and caudal peduncle length (carrying the tail fin), and enhanced snout characters (length, eye diameter and nares separation) going together with reduced trunk and head length and caudal peduncle depth, and vice 
versa. PC2 was positively loaded by HL/SL, BD/SL (both "excellent"), HL/Na ("fair"), and negatively by SLS ("good") and LPF/HL ("fair"). PC2 is a gradient for a long head with widely spaced nares and a deep body going together with a short lateral line and short pectoral fins, and vice versa. PC3 was positively loaded by SLS ("very good") and several "poor" characters (nA, BD/SL, PPF/SL and HL/Na); negatively by LSc/HL and OD/HL ("poor"). It is a gradient for some trunk (SLS, BD and PPF) and fin (nA) characters being increased when certain head characters (LSc, OD, but not $\mathrm{Na}$ ) were reduced, and vice versa.

The Comoé sample of $M$. furcidens compared directly to the Bandama sample of that species proved significantly different in several characters (MANOVA: $\mathrm{F}_{18,6}=16.366, p=0.0012$ ). Pectoral fins (LPF/SL; ANOVA: $\mathrm{F}_{1,23}=42.076, p<0.0001$ ) and anal fins (LA/SL; $\left.F_{1,23}=16.236, p<0.0005\right)$ were longer in the Comoé than Bandama fish, whereas head length (HL/SL, $\mathrm{F}_{1,23}=28.948, p<0.0001$ ), predorsal length $\left(\mathrm{PDL} / \mathrm{SL}, \mathrm{F}_{1,23}=8.551, p=0.0076\right)$ and caudal peduncle length $\left(\mathrm{CPL} / \mathrm{SL}, \mathrm{F}_{1,23}=6.983\right.$, $p<0.015)$ were greater in the Bandama than Comoé fish.

\section{EODs}

The four species all have a biphasic EOD waveform with a head-positive first phase $\mathrm{P}$ followed by a head-negative second phase $\mathrm{N}$ that is typical for all Marcusenius species known so far (Figures 4 and 6). In M. senegalensis, a very small head-negative

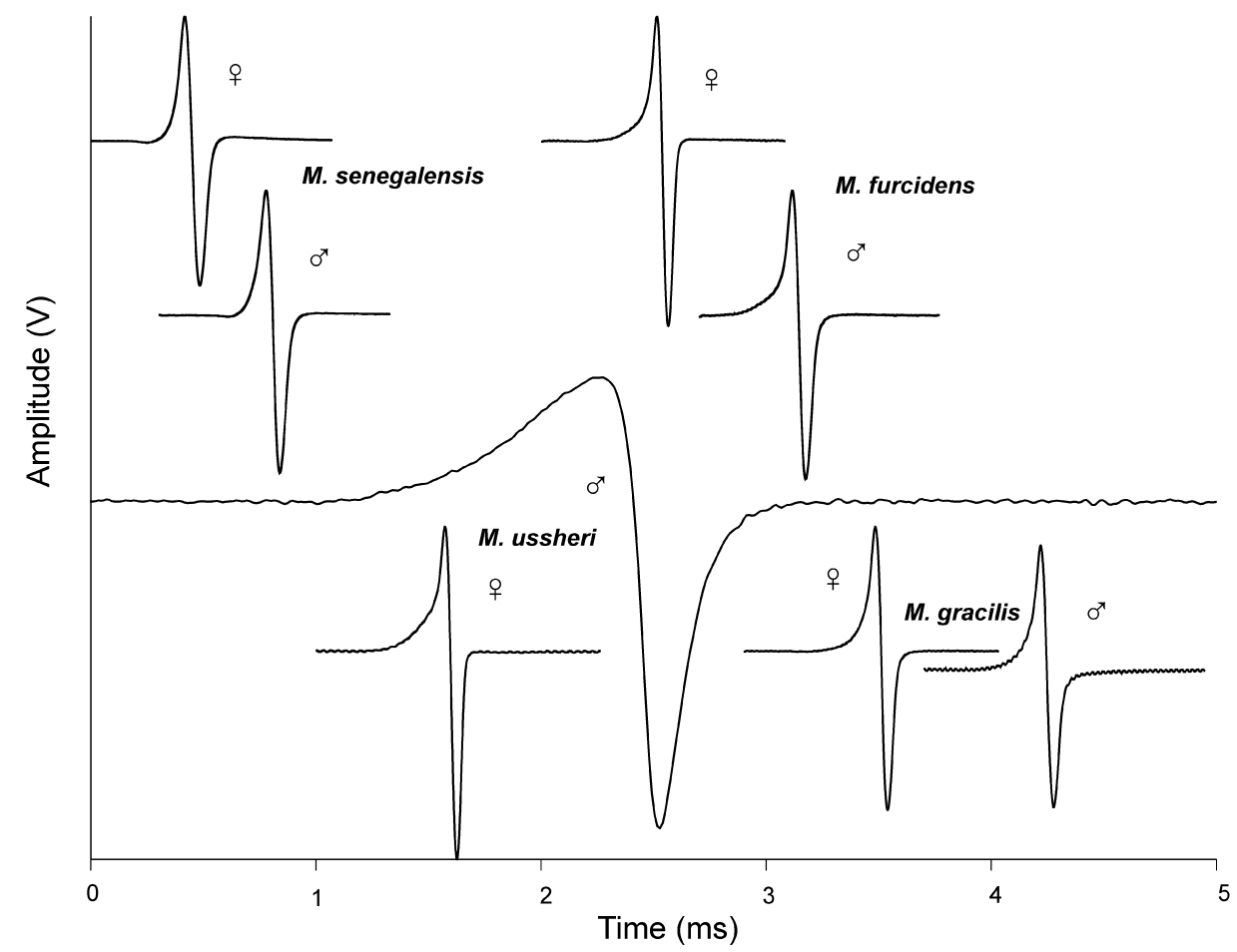

Figure 6. Field recordings of electric organ discharge waveforms of four Marcusenius species of Côte d'Ivoire, with both male and female examples shown. EODs are normalized by $\mathrm{P}$ phase amplitude set equal to 1 Volt from baseline. Same time scale everywhere. 
potential preceded the $\mathrm{P}$ phase whereas in the other samples of the present study, $\mathrm{P}$ phase rose smoothly from baseline. In $M$. senegalensis, an EOD often was terminated by a very small head-positive potential whereas in the other samples $\mathrm{N}$ phase tended to approach baseline asymptotically.

The first question was whether or not there were sex differences. M. senegalensis $(2 \times N=3)$ showed similar EOD characteristics in both sexes (Table 4). Mainly due to $M$. senegalensis' shorter $\mathrm{P}$ phase duration, Pdur, its EOD duration, EODdur $(275.5 \pm \mathrm{SE} 9.9 \mu \mathrm{s}, N=6)$, was shorter than that of any other sample of the present study. Similarly, in M. furcidens specimens (the sex of which was determined by gonad histology because of the absence of the kink character in the anal fin in this species), there was no obvious sex difference, neither in the sample from the Comoé

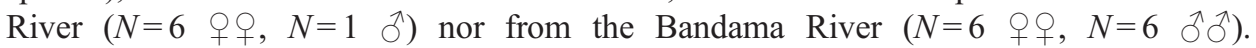
The same conclusion holds for the sample of $M$. gracilis sp. nov. from the Comoé River $(N=6$ oㅇ, $N=1$ §): no obvious sex difference. However, $M$. ussheri from the Bandama River displayed a clear sex difference. In females $(N=6)$, EOD duration was a mean $374.2 \pm 16.2 \mu \mathrm{s}$ whereas in males $(N=6)$ EODdur was a mean $947.3 \pm 219.5 \mu \mathrm{s}$. The longest male EOD was $1820.1 \mu \mathrm{s}, 5.2$ times the average female duration.

As the most advanced ovaries held eggs of stage IV only (I-II in senegalensis), the breeding season had not yet started in April - May when fish were sampled in Côte d'Ivoire. Jégu and Lévêque (1984) give reproduction periods for $M$. ussheri and $M$. furcidens to take place from September to October in the Bandama, and from August November in the Comoé when the rivers are high. According to these authors, the first signs of gonadal recrudescence in females appear in February, and in May-June almost all females have eggs in maturation. This may explain the observation of a vast range of EOD durations in M. ussheri males in the present study (Table 4); apparently only some of the males were ready to breed in April-May.

In DA on correlations among EOD characters, 95\% confidence circles for the two furcidens samples from the Comoé and Bandama rivers were only just overlapping, evidence of some geographical differentiation (Figure 7). The amplitude of the $\mathrm{N}$ phase, Namp, was significantly stronger in the Bandama specimens $(X=-1.70+$ SE $0.04 \mathrm{~V})$ than the Comoé specimens $\left(X=-1.49+0.028 \mathrm{~V}\right.$; ANOVA: $\left.\mathrm{F}_{1,19}=20.15, p=0.0003\right)$. The same holds true for the area under the N phase, Narea: greater values for the Bandama specimens (ANOVA: $\mathrm{F}_{1,19}=4.7, p=0.431$; see Table IV). The circle for $M$. ussheri did not overlap with any other, however, the individual points of the $M$. ussheri sample were widely scattered, a consequence of ussheri's higher EOD waveform plasticity associated with the sex difference. At some distance from these species, the confidence circles for $M$. senegalensis and $M$. gracilis sp. nov. were partially overlapping. In $M$. gracilis sp. nov., the $\mathrm{P}$ phase rose slowly from baseline, whereas in $M$. senegalensis, the $\mathrm{P}$ phase followed a small head-negative pre-potential and hence rose more resolutely. A negative pre-potential has not been seen in the present sample of M. gracilis sp. nov., nor a tiny head-positive post-potential as occurring in the EODs of M. senegalensis. These small pre- and post-potentials were not measured and not entered in DA.

Ten specimens (22\%) out of 46 were misclassified in DA, none of them M. senegalensis, and only one gracilis sp. nov. (as a senegalensis). One specimen out of nine furcidens (Bandama) was misclassified as furcidens (Comoé), and one of three misclassified furcidens (Comoé) as a furcidens (Bandama) and two as ussheri specimens. Five 


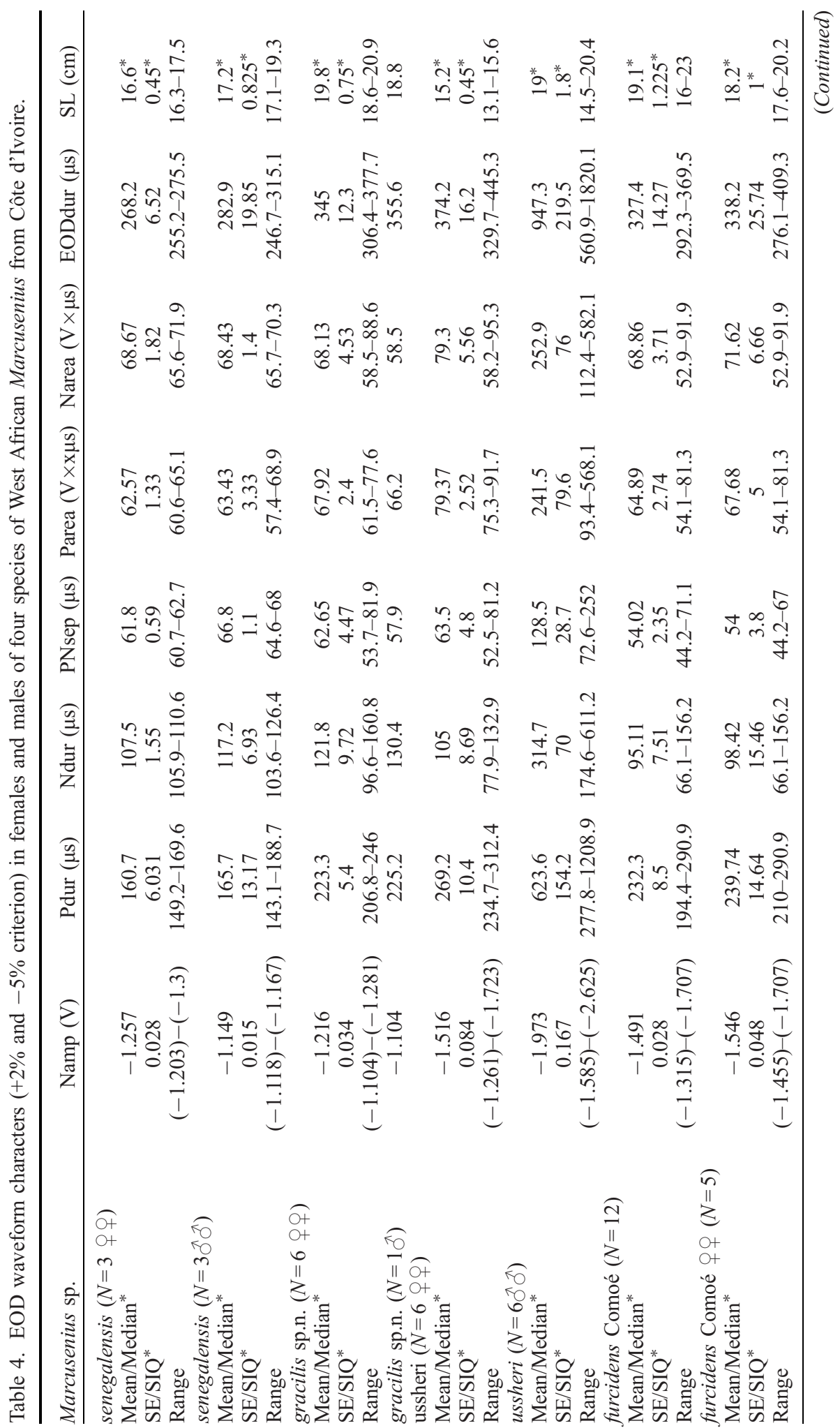




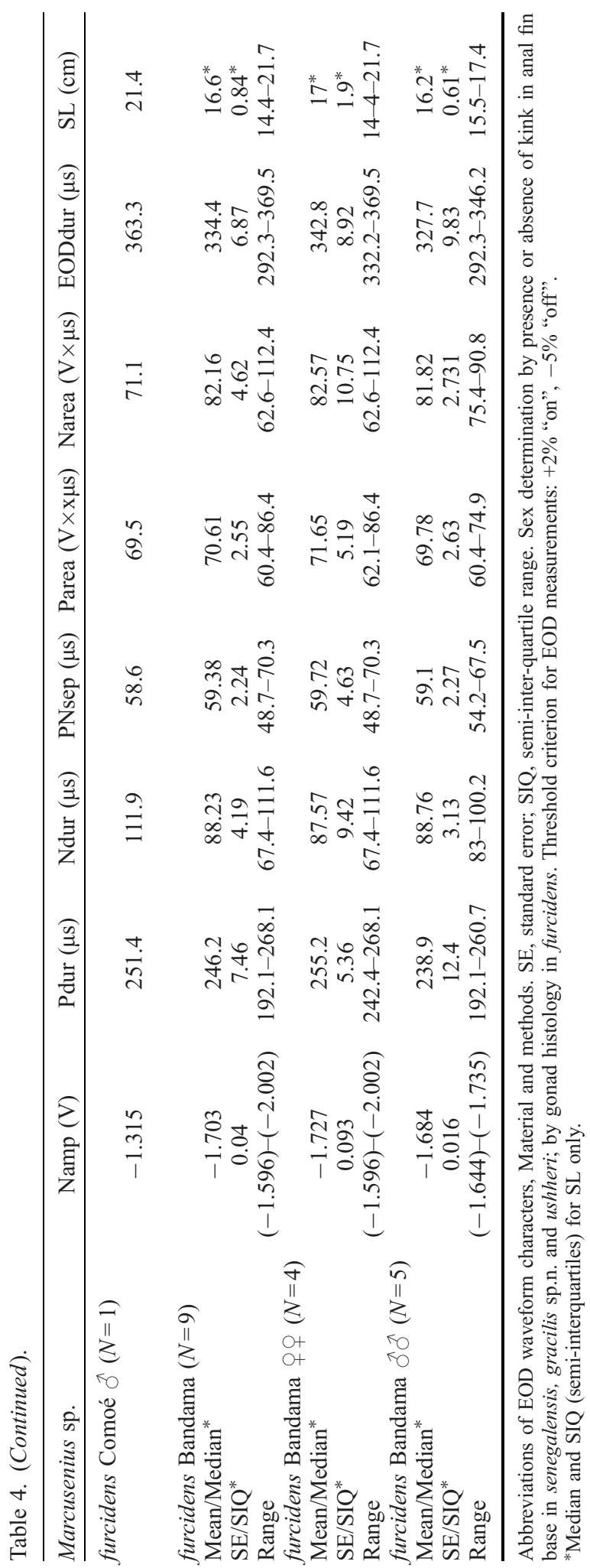




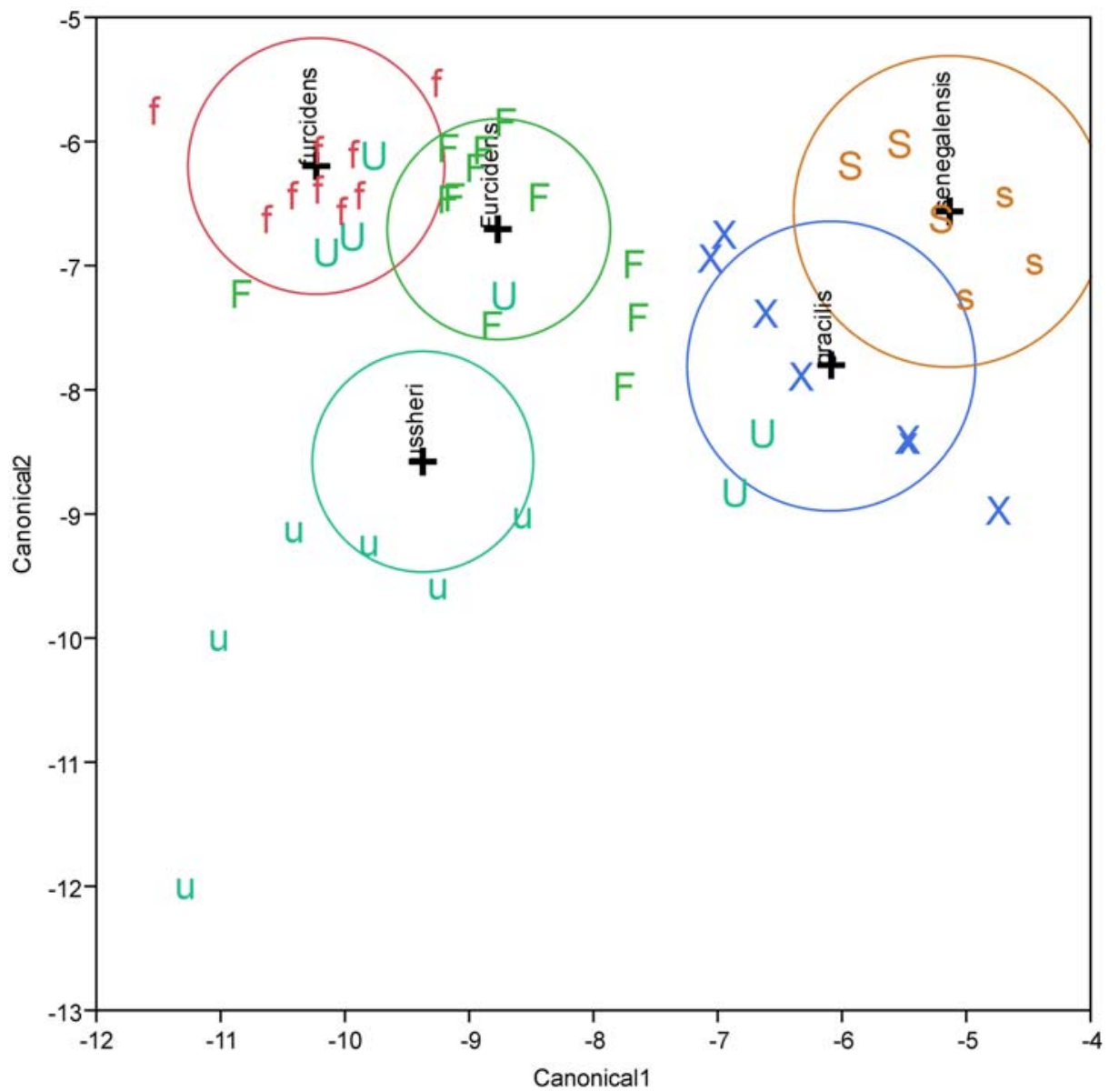

Figure 7. Discriminant analysis on correlations of six EOD waveform characters in four Marcusenius species of Côte d'Ivoire, with 95\% confidence circles to contain true mean of group. F symbols, $M$. furcidens (Comoé River, $N=12$ ); f symbols, $M$. furcidens (Bandama River, $N=9$ ); $\mathrm{X}$ and $\mathrm{x}$ symbols, $M$. gracilis sp. nov. females $(N=6)$ and a male $(N=1)$, respectively (Comoé River); $\mathrm{U}$ and u symbols, $M$ ussheri females $(N=6)$ and males $(N=6)$, respectively (Bandama River); S and s symbols, $M$. senegalensis females $(N=3)$ and males $(N=3)$, respectively (Comoé River). Characters used in analysis: Namp, Pdur, Ndur, PNsep, Parea, Narea. EOD analysis threshold criterion: $+2 \%$ (start) and $-5 \%$ (stop).

out of 12 ussheri were misclassified; three as furcidens (Bandama) specimens and two as gracilis sp. nov. specimens, because they were too far from their mean.

Amplitude spectra of the EODs shown in Figure 6 were similar among the four species and did not notably differ between the sexes, except for M. ussheri males (see below). All species showed broad peaks at frequencies between 3777 to $5169 \mathrm{~Hz}$, and $-10 \mathrm{~dB}$ values (relative to the peak power frequency, PPF) were greater than $441 \mathrm{~Hz}$ on the low-frequency side and between 10,499 and $14,173 \mathrm{~Hz}$ on the high-frequency side. On the low-frequency side, $-20 \mathrm{~dB}$ values were between $131 \mathrm{~Hz}$ and $461 \mathrm{~Hz}$, and on the high-frequency side between 13,264 and 17,661 Hz.

The PPF of the M. ussheri male EOD of Figure 6 was $598 \mathrm{~Hz}$, or seven times lower than the female's. Also lower were the $-10 \mathrm{~dB}$ values (re: PPF amplitude) of the male's EOD at 114 and $2519 \mathrm{~Hz}$ for the low- and high-frequency sides, respectively. On the 
low-frequency side, $-20 \mathrm{~dB}$ values were $196 \mathrm{~Hz}$ in the M. ussheri female compared to only $35 \mathrm{~Hz}$ in the male.

\section{Systematics}

Genus Marcusenius Gill, 1862

Diagnosis (translation of Taverne 1971a).

Body moderately elongated; snout rather low, shorter than postorbital segment of the skull and chin with mental swelling; caudal peduncle 2 to 5 times longer than deep; dorsal fin with 19 to 36 rays; anal fin with 25 to 43 rays; pectoral fin with 10 to 12 rays; 38 to 98 scales in lateral series; 8 to $26 / 12$ to 28 in transversal line at the level of the body; 7 to 21 / 7 to 21 scales in transversal line between dorsal and anal fins; 8 to 18 scales around caudal peduncle; 3 to $8 / 3$ to 10 conical or bicuspid teeth; lateral ethmoid present and well developed; mesethmoid small and straight; 5 circumorbital bones; pre-orbital and first infraorbital fused; 5 hypural bones; 42 to 49 vertebrae.

Taverne (1971b) also gives a diagnosis including more detail on skeletal characters that are not dealt with in the present paper. The phylogeny given in Taverne 1972 specifies that Marcusenius Gill, 1862 shares a lateral ethmoid with five other mormyrid genera; it shares five rather than six circumorbital bones only with two of these genera, and a reduced upper jaw with none).

Type species: Marcusenius cyprinoides (Linnaeus, 1758)

West African Marcusenius species, following Bigorne (2003)

abadii, Gnathonemus Boulenger, 1901. Current status: Valid as Marcusenius abadii (Boulenger, 1901).

brucii, Gnathonemus Boulenger, 1910. Current status: Valid as Marcusenius brucii (Boulenger, 1910).

cyprinoides, Mormyrus Linnaeus, 1758. Current status: Valid as Marcusenius cyprinoides (Linnaeus, 1758).

furcidens, Gnathonemus Pellegrin, 1920. Current status: Valid as Marcusenius furcidens (Pellegrin, 1920).

gracilis, Marcusenius Kramer, 2013.

mento, Mormyrus Boulenger, 1890. Current status: Valid as Marcusenius mento (Boulenger, 1890).

meronai, Marcusenius Bigorne and Paugy, 1990.

senegalensis, Mormyrus Steindachner, 1870. Current status: Valid as Marcusenius senegalensis (Steindachner, 1870).

thomasi, Gnathonemus Boulenger, 1916. Current status: Valid as Marcusenius thomasi (Boulenger, 1916).

ussheri, Mormyrus Günther, 1867. Current status: Valid as Marcusenius ussheri (Günther, 1867).

\section{Marcusenius furcidens (Pellegrin, 1920)}

Gnathonemus furcidens Pellegrin, 1920, p 117.

Marcusenius furcidens (Pellegrin, 1920): Taverne 1971, p. 103. 
Type specimens. Syntypes: MNHN 1920-0030 to 0032 (1, 1, 1); not studied. Type locality. "Lagune Comoé”, Côte d'Ivoire.

Material examined. Seventeen specimens, ZSM 42214 (field nos KafST2, 16.4, Kaf002), 16 Apr 1990; ZSM 42216 (Kaf016, Kaf017, Kaf021, Kaf022), 18 Apr 1990; ZSM 42211 (Kaf029, Kaf034), 20 Apr 1990; ZSM 42213 (Kaf036, Kaf037, Kaf039), 21 Apr 1990; ZSM 42215 (Kaf050), 24 Apr 1990; ZSM 42210 (Kaf053), 26 Apr 1990; ZSM 42217 (Kaf100, Kaf106, Kaf110, Kaf113), 16-26 Apr 1990, all Côte d' Ivoire: Comoé River: Kafolo: Campement de Recherche sur les Mouches Tsétsé, 9³6' N, $4^{\circ} 19^{\prime}$ W, coll. B. Kramer.

Nine specimens, ZSM 42218 (field nos Lam13, Lam14, Lam15, Lam16, Lam17, Lam18), 20 Apr 1991; ZSM 42212 (Lam40, Lam44, Lam48), 22 Apr 1991, all Côte d' Ivoire: Bandama River: Station d’Écologie de Lamto, $6^{\circ} 11^{\prime} \mathrm{N}, 5^{\circ} 0^{\prime} \mathrm{W}$, coll. B. Kramer.

\section{Marcusenius gracilis sp. nov}

Type specimens. Holotype: ZSM 42204 (field no. 201/45/46/48, Ō, SL $22.1 \mathrm{~cm}$ ), 23 Apr 1990; from Côte d' Ivoire: Comoé River: Kafolo: Campement de Recherche sur les Mouches Tsétsé, $9^{\circ} 36^{\prime} \mathrm{N}, 4^{\circ} 19^{\prime} \mathrm{W}$, coll. B. Kramer.

Paratypes (16, studied): ZSM 42197 (field nos Kaf001, Kaf007), 16 Apr 1990; ZSM 42198 (Kaf015, Kaf018), 18 Apr 1990; ZSM 42200 (Kaf027), 19 Apr 1990; ZSM 42196 (Kaf030), 20Apr 1990; ZSM 42199 (Kaf038), 21 Apr 1990; ZSM 42221 (46.48), 23 Apr 1990; ZSM 42201 (Kaf049), 24 Apr 1990; ZSM 42220 (Kaf051, †, SL 19.4 cm), 24 Apr 1990; ZSM 42202 (Kaf054), 26 Apr 1990; ZSM 42203 (Kaf102, Kaf109, Kaf111, Kaf112, Kaf114), 16-26 Apr 1990; all Côte d' Ivoire: Comoé River: Kafolo: Campement de Recherche sur les Mouches Tsétsé, 9³6№ $4^{\circ} 19^{\prime} \mathrm{W}$, coll. B. Kramer.

Type locality. Côte d'Ivoire: Comoé River: Kafolo $\left(9^{\circ} 36^{\prime} \mathrm{N}, 4^{\circ} 19^{\prime} \mathrm{W}\right)$, where it forms the border between Côte d' Ivoire and Burkina Faso.

Differential Diagnosis. Marcusenius gracilis sp. nov. has notched teeth, therefore, all West African species with conical rather than notched teeth, such as senegalensis, abadii, brucii and cyprinoides are excluded (senegalensis also by a smaller eye diameter and a deeper caudal peduncle; both non-overlapping). A much smaller dorsal to anal fin base ratio distinguishes $M$. thomasi $(\mathrm{LD} / \mathrm{LA}<0.7)$ from $M$. gracilis sp. nov. (LD/LA $>0.79)$, whereas $M$. mento is characterized by a higher number of lateral line scales (SLS $\geqslant 76$ (Bigorne 2003) or $\geqslant 79$ (Hopkins et al. 2007)) than M. gracilis (SLS $\leqslant 77)$. M. ussheri is excluded by its lower number of lateral line scales $(\mathrm{SLS} \leqslant 65$ vs. $\geqslant 70$ ), its smaller pectoral fin length to head length ratio (LPF/HL $<0.9$ vs. $>0.9$ ) and its usually deeper caudal peduncle (ratio of caudal peduncle depth to length, $\mathrm{CPD} / \mathrm{CPL}>0.3$ vs. $<0.32$ ). M. furcidens is distinguished by a combination of its higher count of dorsal fin rays $(\mathrm{nD} \geqslant 29$ vs. $\leqslant 30$ in gracilis), longer dorsal fin $(\mathrm{LD} / \mathrm{SL} \geqslant 0.23)$, higher ratio of dorsal to anal fin base $(\mathrm{LD} / \mathrm{LA} \geqslant 0.78)$ and greater body depth $(\mathrm{BD} / \mathrm{SL} \geqslant 0.23)$. M. furcidens males have no distinct kink in the anal fin base, in contrast to the males of $M$. gracilis sp. nov. which do. Relative to the $\mathrm{P}$ phase of its EOD (Figure 4), M. furcidens EODs have a stronger $\mathrm{N}$ phase amplitude than those of $M$. gracilis sp. nov. $(<-1.31$ in furcidens vs. $>-1.28$ re: Pamp $=+1 \mathrm{~V}$ in gracilis). 
Description. Head with terminal mouth well in front of eye, a strongly swollen chin on lower jaw protruding beyond upper jaw. Head and body dorsolaterally compressed. Dorsal fin origin situated close to, but less than two thirds of standard length from snout, obliquely orientated, anteriorly higher and posteriorly lower, distal margin crescentic with anterior two or three rays longer than posterior rays, number of rays $26(N=3), 27$ $(N=9), 28(N=4), 30(N=1)$; anal fin opposite dorsal fin with more anterior origin than dorsal by 6 or 7 rays, obliquely orientated, anteriorly lower and posteriorly higher, anterior rays longer than posterior ones, especially in males where they also appear stronger and often darkened, distal margin crescentic (in males only posterior to rounded, elongated anterior part of fin), number of rays $31(N=2), 32(N=8), 33(N=4), 34(N=2)$, $35(N=1)$. Pectoral fins about as long as head length $(90-107 \%)$, extending beyond the origin of the base of the pelvic fins. Diameter of the eye one-fifth to one-quarter of the length of the head. Body depth around one quarter of SL (21.4-26.6\%). Caudal peduncle slender, subcylindrical entire length, usually 28.2\% (24.7-31.9\%) in CPL (Table 1). Scales on caudal peduncle circumference, $12(N=17)$. Scales cycloid with reticulate striae, scales extending anteriorly to operculum and pectoral fins (beyond pelvics). Teeth notched; lower/upper jaw, variation from 3-7 / 3-6. EOD biphasic (Figure 6); EOD pulse duration $306-380 \mu \mathrm{s}\left(N=7 ; 25^{\circ} \mathrm{C}, " 2 \%\right.$ and $5 \%$ criterion"). Males approaching sexual maturity develop a kink in the base of the anal fin (e.g. Figure 2) which is absent in juveniles and females where the anal fin base is straight. Colour in life: dark silvery grey with brownish hue, paired fins light and transparent.

\section{Colour in preservation. Brown}

\section{Ecology}

When the fish were captured, the Comoé River was a series of stagnant pools. Some pools were quite deep and inhabitated by hippos who could dive. The river banks were high and steep, and difficult to climb when wet, revealing high water and violent current at other times of the year. Bush cover on rocky islands in the dry river bed was strongly bent downstream. The river was sparsely accompanied by gallery forest extending only a precious few meters into the dry bush savannah. The electric catfish was present, also "capitaine" (Lates niloticus Linnaeus, 1762) and large catfish, probably Clarias gariepinus (Burchell, 1822).

Distribution. M. gracilis sp. nov. has at present only been found in the Comoé River close to Kafolo where it forms the border between Côte d'Ivoire and Burkina Faso.

Relationships. From the morphological analysis it appears M. gracilis sp. nov. is most closely related to $M$. furcidens, less closely to $M$. ussheri, and much less closely to $M$. senegalensis.

\section{Etymology}

Marcusenius gracilis sp. nov. is more slender than the other Ivorian and many of the West African Marcusenius species, including M. furcidens.

\section{Marcusenius mento (Boulenger, 1890)}

Mormyrus mento Boulenger, 1890, p. 193. 
Gnathonemus mento Boulenger 1898, p. 807

Marcusenius mento Taverne 1971a, p. 103

Type specimens. Holotype BMNH 1881.7.20, “A single specimen”; studied.

Type locality. "from the Gabon".

\section{Marcusenius senegalensis (Steindachner, 1870)}

Mormyrus senegalensis Steindachner, 1870, p. 551.

Gnathonemus senegalensis Boulenger 1898, p. 806.

Marcusenius senegalensis Taverne 1971, p. 103.

Type specimens. Syntypes NMW 55.109-55.110 (2); not studied.

Type locality. "Marigot von Taoué, Dagana”, Senegal.

\section{Material examined}

Eleven specimens, ZSM 42193 (field no. Kaf011), 17 Apr 1990; ZSM 42190 (Kaf033 and Kaf035), 20 Apr 1990; ZSM 42192 (Kaf040, Kaf041), 21 Apr 1990; ZSM 42195 (45 and Kaf047), 23 Apr 1990; ZSM 42191 (Kaf052), 24 Apr 1990; ZSM 42194 (Kaf103, Kaf104, Kaf115), 16 - 26 Apr 1990; all Côte d' Ivoire: Comoé River: Kafolo: Campement de Recherche sur les Mouches Tsétsé, 9³6’ N, 4¹9’ W, coll. B. Kramer.

\section{Marcusenius ussheri (Günther, 1867)}

Mormyrus ussheri Günther, 1867, p. 116.

Gnathonemus ussheri Boulenger 1898, p. 808.

Marcusenius ussheri Taverne 1971, p. 103

Type specimens. Holotype BMNH 1864.4.12: 8; not studied.

Type locality. "Bossumprah River, Gold Coast".

Material examined. Sixteen specimens, ZSM 42207 (field nos Lam61, Lam64, Lam66, Lamto Marc 100, Lam101, Lamto), 1 May 1990; ZSM 42205 (Lam009-012), 12 Apr 1991; ZSM 42206 (Lam06), 13 Apr 1991; ZSM 42209 (Lam20, Lam21, Lam22), 20 Apr 1991; ZSM 42208 (Lam41, Lam42, Lam45, Lam46, Lam47), 22 Apr 1991, all Côte d' Ivoire: Bandama River: Station d'Écologie de Lamto, $6^{\circ} 11^{\prime} \mathrm{N}, 5^{\circ} 0^{\prime} \mathrm{W}$, coll B. Kramer.

\section{Discussion}

The present paper adds a new Marcusenius species, M. gracilis sp. nov., to the three known ones for Côte d'Ivoire, M. furcidens, M. ussheri and M. senegalensis. M. gracilis sp. nov. resembles most closely $M$. furcidens that occurs in both rivers in contrast to M. gracilis sp. nov. that was recovered from the Comoé River but not the Bandama. $M$. gracilis sp. nov. is distinguished from $M$. furcidens by its lower scores for characters loading most strongly and positively on Principal Component 1 ( $\mathrm{PC} 1$, such as $\mathrm{nD}, \mathrm{LD}$, 
LD/LA, pD) and on PC2 (BD), as also confirmed by MANOVA/ANOVA. These characters mainly refer to the rear section of the body and its depth, that is, swimming power and manoeuvrability. Both $M$. gracilis sp. nov. and $M$. furcidens share a long and slender caudal peduncle, and long and sharply pointed tail fin lobes compared with the other two species. The males of M. gracilis sp. nov. and M. furcidens differ categorically in the presence of a kink in the anal fin base only of the former species. A kink was also observed in the males of the other two Ivorian Marcusenius species, and is present in many other mormyrid species as well (e.g. Pezzanite \& Moller 1998).

The EODs of all species studied in the present paper resembled each other: a strong $\mathrm{P}$ phase was followed by a strong $\mathrm{N}$ phase, sometimes centred by very weak leading and trailing miniature potentials (such as in M. senegalensis, Figures 4 and 6). The EODs of $M$. gracilis sp. nov. and $M$. furcidens differed in that $M$. gracilis' EOD has a consistently weaker $\mathrm{N}$ phase amplitude (relative to $\mathrm{P}$ phase amplitude). M. ussheri males differed from those of the other Ivorian Marcusenius species in displaying an EOD of much longer duration than that of their females. The EOD amplitude spectra of male M. ussheri were therefore the only ones to display a marked low-frequency content whereas the EODs of all other samples did not (Figure 8). The $-20 \mathrm{~dB}$ attenuation relative to the peak power frequency (re: PPF) of an EOD of a male M. ussheri with long discharge was observed at $35 \mathrm{~Hz}$ on the low frequency side, in contrast to all other fish where this value ranged from 131 to $461 \mathrm{~Hz}$. The PPF of the ussheri males' EOD was at $598 \mathrm{~Hz}$ compared to 3800$5200 \mathrm{~Hz}$ in the other fish. The ussheri males' spectrum was shifted to low frequencies by almost one order of magnitude compared to the female's (Figure 8, lower right panel).

The low-frequency energy of its EOD makes M. ussheri males vulnerable to electroreceptive predators such as the ubiquitous catfish Clarias gariepinus of marked low-frequency sensitivity (Lissmann \& Machin 1963), as has been shown for the males of the southern African Marcusenius altisambesi Kramer et al. 2007 with a similar sexual dimorphism of its EOD (Hanika \& Kramer 2000). The great range of male EOD duration values $(561-1820 \mu \mathrm{s})$ in contrast to the females' $(330-445 \mu \mathrm{s})$ suggests only a seasonal dimorphism in male EOD duration, as has been observed in $M$. altisambesi (Kramer 1997a, 1997b; Kramer et al. 2007). In April-May when fish were sampled the reproductive season had not yet begun in Côte d'Ivoire, although gonadal recrudescence had already been observed starting February (Jégu \& Lévêque 1984).

Moritz et al. (2008) showed similar EODs for M. senegalensis from the Upper Volta system. Their PPF values are higher than those in the present paper, probably because of a higher mean temperature that usually varied from 26.5 to $32.3^{\circ} \mathrm{C}$, but could also reach $41.0^{\circ} \mathrm{C}$ in one place. Unlike the present paper, EODs were not normalized to a specific temperature in the 2008 paper. The 2008 amplitude spectra are almost flat, showing low frequencies at high intensities (only about $2 \mathrm{~dB}$ attenuation re: PPF). As Moritz et al. (2008) did not give methods details for their FFT analyses, the reasons for this lack of dynamic range in their spectra cannot be ascertained. The present paper does not confirm this result, and all Marcusenius of the present study but M. ussheri males (probably only when in or approaching breeding condition) should be safe from detection by predators relying on low-frequency ampullary electroreceptor organs (that is, bichirs, predatory catfish species and one lungfish species for West Africa; Paugy et al. 2003). None, however, are safe from mormyriform predators with their two additional types of electroreceptor organ that are sensitive to higher frequencies (Peters 2009), such as Gymnarchus niloticus Cuvier, 1829 or Mormyrops species.

The comparison of the two M. furcidens samples from the two rivers yielded some differentiation: pectoral fin (PPF/SL) and anal fin lengths (LA/SL) were significantly 

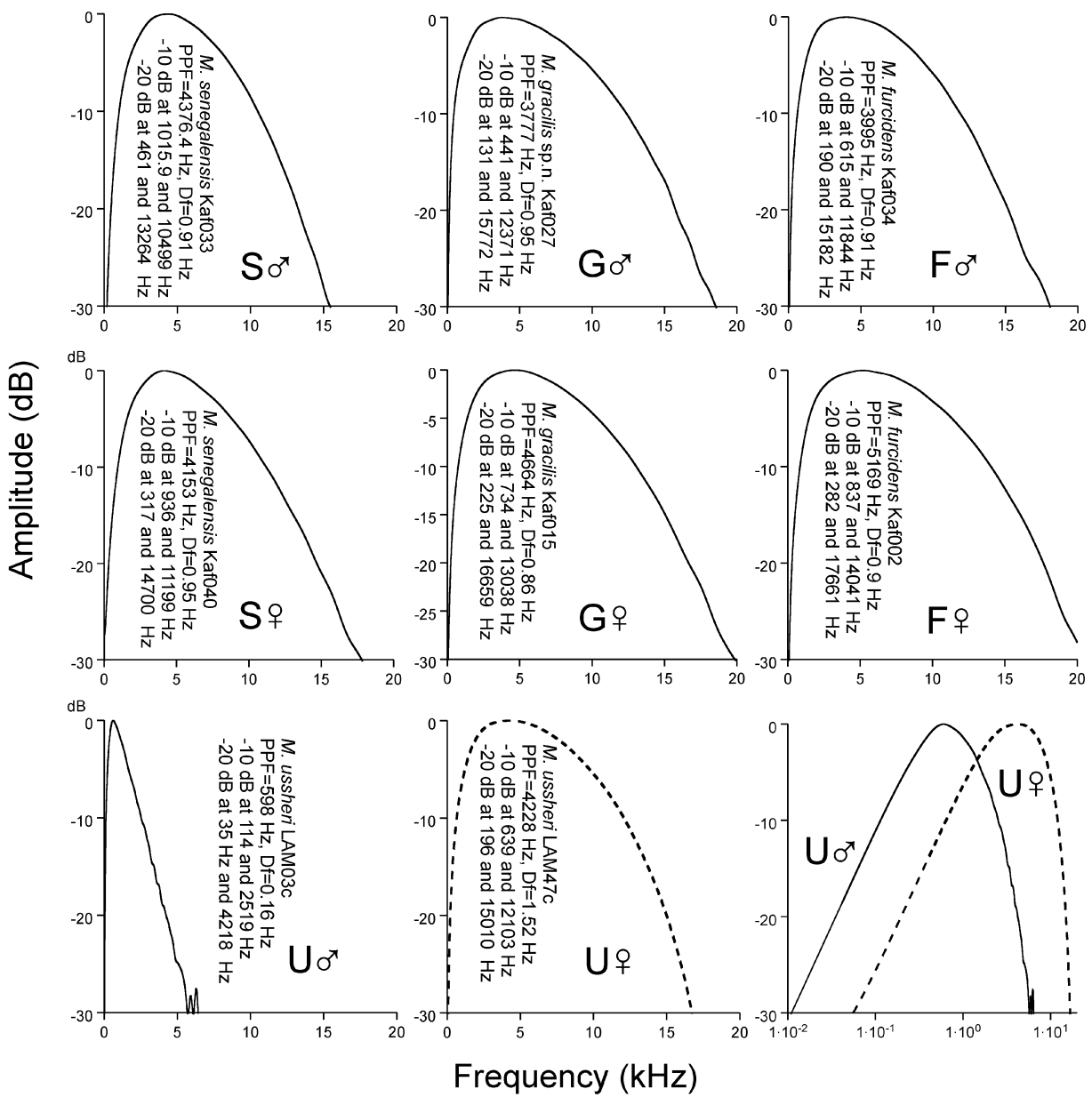

Figure 8. Amplitude spectra of single EOD pulses of Marcusenius species. Ordinates, amplitudes relative to the strongest spectral signal component $=0 \mathrm{~dB}$. Abscissae, frequency in $\mathrm{kHz} . \mathrm{S} \hat{\jmath}, \mathrm{S}$, spectra for an $M$. senegalensis male and female; $\mathrm{G}^{\lambda}, \mathrm{G}+$, M. gracilis sp. nov. male and female;

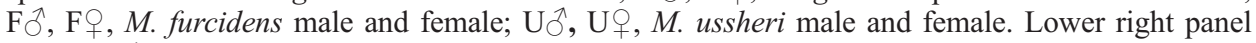
shows $U_{\hat{o}}$ and $U$ + together in one graph with logarithmic abscissa $(10-20,000 \mathrm{~Hz})$. Df, spectral frequency resolution; PPF, peak power frequency; frequencies at -10 and $-20 \mathrm{~dB}$ re: $0 \mathrm{~dB}$ both on the low and the high frequency side.

greater, and head length (HL/SL), predorsal length (PDL/SL) and caudal peduncle length (CPL/SL) significantly shorter in the Comoé specimens, whereas the $\mathrm{N}$ phase amplitude, Namp, of the EOD was stronger in the Bandama specimens. There is a lot of differentiation between the members of a single species that asks for explanation and further investigation.

The intermittent Comoé River runs through a dry Sahel zone and is a harsh environment for fish compared with the perennial Bandama River in its stable tropical rain forest setting. Seasonal extreme changes in water volume, a reduction to a series of pools in the dry season and violent flooding in the few months of the wet season are characteristics for the Comoé River. In the pools water temperature and conductivity rise to high values and oxygen levels are low. Mormyrids cannot breathe atmospheric air like catfish or G. niloticus do. These harsh conditions certainly require adaptations in life 
history and reproduction, as discussed by Paugy (2002) for a similar West African River, the Baoulé in Mali. These ecological differences could be the basis for some of the observed differentiation between the two furcidens samples, e.g. in fin length.

In the Comoé, three Marcusenius species of similar EOD pulse waveform were recovered, and a fourth species (again with similar EOD, judging from their Bandama conspecifics) is known to be present but was only caught in the Bandama (M. ussheri). The question arises as to the communication function of the EOD and its species specificity, and how densely species that are so closely related can be packed into the same river. Their differentiation has in part been unrecognized up to now. Marcusenius is a big genus with only small species-characteristic variations of a basically similar EOD among its members (e.g. Kramer et al. 2007) and this is confirmed in the present study. This is in contrast to other mormyrid genera like Hippopotamyrus (Kramer et al. 2004; Kramer \& Swartz 2010), Pollimyrus (Kramer et al. 2003, unpublished) or Mormyrus (Kramer 2013) where radically different EOD waveforms among close relatives are also present. In Marcusenius altisambesi and M. pongolensis (Fowler, 1934) of southern Africa, the relevance of individually variable EOD waveform characteristics has been demonstrated in male-male competition and sexual attraction (Hanika and Kramer 2005, 2008; Machnik and Kramer 2008a, 2008b; Machnik et al. 2010). Whereas $M$. ussheri males generate an unmistakable EOD of enhanced pulse length and low spectral frequency, the signals of the other three species, although differentiated as shown, are so similar they appear to ask for superior sensory discrimination mechanisms. Such mechanisms have been demonstrated in food-rewarded, trained Pollimyrus adspersus (Günther, 1866) and Gnathonemus petersii (Günther, 1862) in conditioned discrimination experiments (Graff \& Kramer 1992; Paintner \& Kramer 2003), and a similar sensory acuity is likely from the results of spontaneous choice experiments using untrained specimens of southern African Marcusenius and Pollimyrus species (M. altisambesi and M. pongolensis, P. castelnaui (Boulenger, 1911) and P. marianne Kramer et al., 2003). Why should they not be present also in the Ivorian Marcusenius.

The three southern African Marcusenius species, M. altisambesi, M. pongolensis and M. macrolepidotus (Peters, 1852) vocalize intensely during aggression and courtship, and the acoustic characteristics of the vocalizations differ among species (Lamml \& Kramer 2007). Since the vocalizing is restricted to periods of intense interaction with conspecifics, in contrast to EODs which are generated throughout these fishes' life, the vocal signals may be the ones that are critical in initial pair contact and pair formation before spawning (Bratton \& Kramer 1989; Crawford et al. 1986, 1997; Lamml \& Kramer 2006). Mormyrid fish have excellent hearing (Kramer et al. 1981; Marvit \& Crawford 2000a, 2000b). An important function of vocalizations in reproductive context is conceivable also because of the greater reach of acoustic underwater signals which are generated by the equivalent of a point source, where the sound intensity is inversely proportional to the square of the distance (Hassall \& Zaveri 1979), compared to electric signals generated by a dipole, where the electrical field gradient falls off with the inverse cube of the distance (Knudsen 1974). The Ivorian Marcusenius species have not yet been studied regarding vocalizations but it would be highly surprising if they did not vocalize, which would give them an additional means of species-specific, nocturnal signalling.

\section{Acknowledgements}

Many thanks go to Prof R. Vuattoux, Station d'écologie de Lamto, and Prof M. Mühlenberg, then University of Würzburg, for support and hospitality in Côte d'Ivoire and the Government of Côte d'Ivoire for granting permissions. Dr D. Paugy, then Muséum d'Histoire Naturelle, Paris, for 
help with initial species identification of and morphological information on West African Marcusenius species. James Maclaine and Ms Tracy Heath, Natural History Museum, London, for the loan of M. mento. Dr U. Schliewen and D. Neumann, Zoologische Staatssammlung München, for institutional collection support. Prof P. Moller, Hunter College, New York, for joint field trip to Ivory Coast together with M. Postner; second trip with I. Kaunzinger. Great thanks also to Regensburg morphology team: B. Otto, E. Fröhlich, S. Förster, B. Blaul, S. Füssel, T. Gierl, S. Hartl, M. Lange, A. Lechner, P. Machnik. Supported by Deutsche Forschungsgemeinschaft, grant KR 446/12-2 and previous grants. This research was conducted with appropriate authorization and permits from the government of Côte d'Ivoire, and in accordance with the laws and guidelines in Côte d'Ivoire and Germany.

\section{References}

Adebisi AA. 1987. The relationships between the fecundities, gonado-somatic indices and egg sizes of some fishes of Ogun river. Nigeria Arch Hydrobiol. 111:151-156.

Agnèse JF, Bigorne R. 1992. Premières données sur les relations génétiques entre onze espèces ouest-africaines de Mormyridae (Teleostei, Osteichthyes) [First data on genetic relationships between eleven species of West African Mormyridae (Teleostei, Osteichthyes)]. Rev Hydrobiol trop. 25:253-261.

Bailey RG. 1989. An appraisal of the fisheries of the Sudd wetlands, River Nile, southern Sudan. Aquaculture Fish Manage. 20:79-89.

Bigorne R. 1990. Mormyridae. In: Lévêque C, Paugy D, Teugels GG, editors. Faune des poissons d'eaux douces et saumâtres de l'Afrique de l'Ouest [The fresh and brackish water fishes of West Africa]. Tervuren (Belgium)/Paris (France): Musée Royal de l'Afrique Centrale/Editions de l'ORSTOM; p. 122-184.

Bigorne R. 2003. Mormyridae. In: Paugy D, Lévêque C, Teugels GG, editors. Poissons d'eaux douces et saumâtres de l'Afrique de l'Ouest [The fresh and brackish water fishes of West Africa]. Vol. 1. Paris: IRD Éditions, Publications scientifiques du Muséum, MRAC; p. 155222.

Bigorne R, Paugy D. 1990. Description de Marcusenius meronai, espèce nouvelle de Mormyridae (Teleostei) de Sierra Leone [Description of Marcusenius meronai, a new species of Mormyridae from Sierra Leone]. Ichthyol Explor Freshwaters. 1:33-38.

Boden G, Teugels GG, Hopkins CD. 1997. A systematic revision of the large-scaled Marcusenius with descriptions of a new species from Cameroon (Teleostei; Osteoglossomorpha; Mormyridae). J Nat Hist. 31:1645-1682.

Boulenger GA. 1898. A revision of the genera and species of the fishes of the family Mormyridae. Proc Zool Soc Lond. 1898:775-821.

Boulenger GA. 1890. Description of a new species of Mormyrus. Ann Mag Nat Hist (Ser.6). 6: 193.

Bracewell RN. 2000. The Fourier transform and its applications, 3rd ed. Boston (MA): McGrawHill.

Bratton BO, Kramer B. 1989. Patterns of the electric organ discharge during courtship and spawning in the mormyrid Pollimyrus isidori. Behav Ecol Sociobiol. 24:349-368.

Crawford JD, Hagedorn M, Hopkins CD. 1986. Acoustic communication in an electric fish, Pollimyrus isidori (Mormyridae). J Comp Physiol A. 159:297-310.

Crawford JD, Hopkins CD. 1989. Detection of a previously unrecognized mormyrid fish (Mormyrus subundulatus) by electric discharge characters. Cybium. 13:319-326.

Crawford JD, Jacob P, Bénech V. 1997. Sound production and reproductive ecology of strongly acoustic fish in Africa: Pollimyrus isidori, Mormyridae. Behavior. 134:677-725.

Davis PJ, Hersh R. 1980. The mathematical experience. Boston (MA): Birkhäuser. 
Fricke R, Eschmeyer WN. 2012. A guide to fish collections in the Catalog of Fishes [Internet]. Online version, updated 6 December 2012. San Francisco: California Academy of Sciences. Available from: http://research.calacademy.org/redirect?url=http://researcharchive.calacademy. org/research/Ichthyology/catalog/fishcatmain.asp

Graff C. 1989. Firing activity of the weakly-electric fish Marcusenius macrolepidotus (Mormyridae, Teleostei): logarithmic repartition of inter-pulse intervals, and sequential inequality testing. Behavior. 109:258-284.

Graff C, Kramer B. 1992. Trained weakly-electric fishes Pollimyrus isidori and Gnathonemus petersii (Mormyridae, Teleostei) discriminate between waveforms of electric pulse discharges. Ethology. 90:279-292.

Günther A. 1867. New fishes from Gaboon and Gold Coast. Ann Mag Nat Hist (Series 3). 20: 110-117, Pls. 2-3.

Hanika S, Kramer B. 1999. Electric organ discharges of mormyrid fish as a possible cue for predatory catfish. Naturwissenschaften. 86:286-288.

Hanika S, Kramer B. 2000. Electrosensory prey detection in the African sharptooth catfish, Clarias gariepinus (Clariidae), of a weakly electric mormyrid fish, the bulldog (Marcusenius macrolepidotus). Behav Ecol Sociobiol. 48:218-228.

Hanika S, Kramer B. 2005. Intra-male variability of its communication signal in the weakly electric fish, Marcusenius macrolepidotus (South African form), and possible functions. Behavior. 142:145-166.

Hanika S, Kramer B. 2008. Plasticity of electric organ discharge waveform in the South African bulldog fish, Marcusenius pongolensis: tradeoff between male attractiveness and predator avoidance? Front Zool. 5:7.

Hassall JR, Zaveri K. 1979. Acoustic noise measurements. Naerum: Brüel \& Kjaer.

Hopkins CD, Lavoué S, Sullivan JP. 2007. Mormyridae. In: Stiassny MLJ, Teugels GG, Hopkins $\mathrm{CD}$, editors. Poissons d'eaux douces et saumâtres de basse Guinée, ouest de l'Afrique centrale [The fresh and brackish water fishes of Lower Guinea, West-central Africa], vol. 1. Paris: IRD Éditions; p. 220-334.

Hyslop EJ. 1986. The food habits of four small-sized species of Mormyridae from the floodplain pools of the Sokoto-Rima river basin, Nigeria. J Fish Biol. 28:147-151.

Jégu M, Lévêque C. 1984. Le genre Marcusenius (Pisces, Mormyridae) en Afrique de l'ouest. [The genus Marcusenius (Pisces, Mormyridae) in West Africa]. Rev Hydrobiol trop. 17:335-358.

Keuper A. 1988. FFT in der Praxis. Grundlagen und Hinweise zur Anwendung der Fast-FourierTransformation [FFT in applications. Foundations and practical tips regarding the Fast Fourier transformation]. Elektronik Journal. 20:104-110.

Knudsen EI. 1974. Behavioral thresholds to electric signals in high frequency electric fish. J Comp Physiol A. 91:333-353.

Kramer B. 1997a. Electric organ discharges and their relation to sex in mormyrid fishes. Naturwissenschaften. 84:119-121.

Kramer B. 1997b. A field study of African elephantfish (Mormyridae, Teleostei): electric organ discharges in Marcusenius macrolepidotus (Peters, 1852) and Petrocephalus catostoma (Günther, 1866) as related to sex. J Afr Zool. 111:313-341.

Kramer B. 2013. A morphological study on species of African Mormyrus (Teleostei: Mormyridae) and their electric organ discharges. Afr J Aquat Sci. 38:1-19.

Kramer B, Westby GWM. 1985. No sex difference in the waveform of the pulse type electric fish, Gnathonemus petersii (Mormyridae). Experientia. 41:1530-1531.

Kramer B. in press. Morphological and electrophysiological field observations on electric freshwater fish of the genus Mormyrops Müller, 1843 (Actinopterygii: TeleosteI: Mormyridae) from West and southern Africa. Afr J Aquat Sci.

Kramer B, Skelton P, van der Bank H, Wink M. 2007. Allopatric differentiation in the Marcusenius macrolepidotus species complex in southern and eastern Africa: the resurrection of $M$. pongolensis and M. angolensis, and the description of two new species (Mormyridae, Teleostei). J Nat Hist. 41:647-708. 
Kramer B, Swartz ER. 2010. A new species of Slender Stonebasher within the Hippopotamyrus ansorgii complex from the Cunene River in southern Africa (Teleostei: Mormyriformes). J Nat Hist. 44:2213-2242.

Kramer B, Tautz J., Markl H. 1981. The EOD sound response in weakly electric fish. J Comp Physiol A. 143:435-441.

Kramer B, van der Bank H, Flint N, Sauer-Gürth H, Wink M. 2003. Evidence for parapatric speciation in the mormyrid fish, Pollimyrus castelnaui (Boulenger, 1911), from the Okavango Upper Zambezi River Systems: P. marianne sp. nov., defined by electric organ discharges, morphology and genetics. Environ Biol Fishes. 67:47-70.

Kramer B, van der Bank FH, Wink M. 2004. The Hippopotamyrus ansorgii species complex in the Upper Zambezi River System with a description of a new species, H. szaboi (Mormyridae). Zoologica Scripta. 33:1-18.

Lamml M, Kramer B. 2006. Differentiation of courtship songs in parapatric sibling species of dwarf stonebashers from southern Africa (Mormyridae, Teleostei). Behavior. 143:783-810.

Lamml M, Kramer B. 2007. Allopatric differentiation in the acoustic communication of a weakly electric fish from southern Africa, Marcusenius macrolepidotus (Mormyridae, Teleostei). Behav Ecol Sociobiol. 61:385-399.

Lévêque C, Paugy D. 1984. Guide des poissons d'eau douce de la zone du programme de lutte contre l'onchocercose en Afrique de l'Ouest [A guide to the freshwater fishes of the programme zone fighting onchocerciasis in West Africa]. Paris: Convention ORSTOM-OMS.

Lévêque C, Paugy D, Teugels GG. editors. 1990. Faune des poissons d'eaux douces et saumâtres de l'Afrique de l'Ouest. Musée Royal de l'Afrique Centrale [The fresh and brackish water fishes of West Africa]. Tervuren (Belgium)/Paris (France): Editions de l'ORSTOM. p. 384.

Leviton AE, Gibbs RH, Heal E, Dawson CE. 1985. Standards in herpetology and ichthyology: part I. Standard symbolic codes for institutional resource collections in herpetology and ichthyology. Copeia. 1985:802-832.

Lissmann HW, Machin KE. 1963. Electric receptors in a non-electric fish (Clarias). Nature. 199:88-89.

Machnik P, Kramer B. 2008a. A male's playback signal turns female Marcusenius pongolensis receivers on or off depending on his behavioural state. Comm Integ Biol. 1:128-131.

Machnik P, Kramer B. 2008b. Female choice by electric pulse duration: attractiveness of the males' communication signal assessed by female bulldog fish, Marcusenius pongolensis (Mormyridae, Teleostei). J Exp Biol. 211:1969-1977.

Machnik P, Kramer B. 2011. Novel electrosensory advertising during diurnal resting period in male snoutfish, Marcusenius altisambesi (Mormyridae, Teleostei). J Ethol. 29:131-142.

Machnik P, Markowski B, Kramer B. 2010. Intra- versus intersexual selection in the dimorphic electric organ discharges of the snoutfish Marcusenius altisambesi (Mormyriformes, Teleostei). Behavior. 147:677-704.

Marvit P, Crawford JD. 2000a. Auditory discrimination in a sound-producing electric fish (Pollimyrus): tone frequency and click-rate difference detection. J Acoust Soc Am. 108:8191825.

Marvit P, Crawford JD. 2000b. Auditory thresholds in a sound-producing electric fish (Pollimyrus): behavioral measurements of sensitivity to tones and click trains. J Acoust Soc Am. 107:2209-2214.

McGarigal K, Cushman S, Stafford S. 2000. Multivariate statistics for wildlife and ecology research. New York: Springer Verlag.

Moller P. 1976. Electric signals and schooling behavior in a weakly electric fish, Marcusenius cyprinoides (Mormyriformes). Science. 193:697-699.

Moritz T, Linsenmair KE, von der Emde G. 2008. Electric organ discharge (EOD) variability of Mormyridae (Teleostei: Osteoglossomorpha) in the Upper Volta system. Biol J Linn Soc. 94:61-80.

Mulisch M, Welsch U, editors. 2010. Romeis - Mikroskopische Technik [Romeis - microscopical techniques], 18th ed. München: Spektrum Akademischer Verlag. 
Paintner S, Kramer B. 2003. Electrosensory basis for individual recognition in a weakly electric, mormyrid fish, Pollimyrus adspersus (Günther, 1866). Behav Ecol Sociobiol. 55:197-208.

Paugy D. 2002. Reproductive strategies of fishes in a tropical temporary stream of the Upper Senegal basin: Baoulé River in Mali. Aquat Living Resour. 15:25-33.

Paugy D, Lévêque C, Teugels GG. 2003. Poissons d'eaux douces et saumâtres de l'Afrique de l'Ouest [The fresh and brackish water fishes of West Africa]. Vol 1+2. Paris: IRD Éditions/ Publications scientifiques du Muséum, MRAC; p. $457+815$.

Pellegrin J. 1920. Poissons des lagunes de la Côte d'Ivoire. Descriptions de deux espèces nouvelles [Fishes of the lagoons of Côte d'Ivoire. Descriptions of two new species]. Bull Soc Zool France. 45:115-121.

Peters RC. 2009. Electroreceptor organs. In: Binder MD, Hirokawa N, Windhorst U, editors. Encyclopedia of neuroscience. Berlin Heidelberg: Springer-Verlag; p. 1078-1083.

Pezzanite B, Moller P. 1998. A sexually dimorphic basal anal-fin ray expansion in the weakly discharging electric fish Gnathonemus petersii. J Fish Biol. 53:638-644.

Planquette P, Lemasson J. 1975. Le peuplement de poissons du Bandama blanc en pays Baoulé [The fish populations of the White Bandama in the Baoulé region]. Ann Univ Abidjan (Série E). 8(1): 75-121.

Roberts TR. 1989. Mormyrus subundulatus, a new species of mormyrid fish with a tubular snout from West Africa. Cybium. 13:51-54.

Scheffel A, Kramer B. 1997. Electrocommunication and social behaviour in Marcusenius senegalensis (Mormyridae, Teleostei). Ethology. 103:404-420.

Skelton P. 2001. A complete guide to the freshwater fishes of southern Africa. Cape Town: Struik Publishers.

Steindachner F. 1870. Zur Fischfauna des Senegal (mit 8 Tafeln) [A supplement to the fishes of Senegal (with 8 plates)]. Sitzungsberichte der Kaiserlichen Akademie der Wissenschaften. Mathematisch-Naturwissenschaftliche Classe, 61 (1. Abth.): 533-583.

Tabachnick BG, Fidell LS. 2007. Using multivariate statistics, 5th ed. Boston (MA): Pearson Education.

Takashima F, Hibiya T, editors. 1995. An atlas of fish histology. Normal and pathological features. Stuttgart: Gustav Fischer Verlag.

Taverne L. 1971a. Note sur la systématique des poissons Mormyriformes. Le problème des genres Gnathonemus Gill, Marcusenius Gill, Hippopotamyrus Pappenheim, Cyphomyrus Myers et les nouveaux genres Pollimyrus et Brienomyrus [Note on the systematics of mormyriform fishes. The problem of the genera Gnathonemus Gill, Marcusenius Gill, Hippopotamyrus Pappenheim, Cyphomyrus Myers and the new genera Pollimyrus and Brienomyrus]. Rev Zool Bot Afr. 84(1-2):99-110.

Taverne L. 1971b. Ostéologie des genres Marcusenius Gill, Hippopotamyrus Pappenheim, Cyphomyrus Myers, Pollimyrus Taverne et Brienomyrus Taverne (Pisces Mormyriformes) [Osteology of the genera Marcusenius Gill, Hippopotamyrus Pappenheim, Cyphomyrus Myers, Pollimyrus Taverne and Brienomyrus Taverne (Pisces Mormyriformes)]. Musée Royal de l'Afrique Centrale - Tervuren, Belgique: Annales - Série in- $8^{\circ}-$ Sciences Zoologiques 188: $\mathrm{x}-144+3$ plates.

Taverne L. (1972). Ostéologie des genres Mormyrus Linné, Mormyrops Müller, Hyperopisus Gill, Isichthys Gill, Myomyrus Boulenger, Stomatorhinus Boulenger et Gymnarchus Cuvier. Considérations générales sur la systématique des poissons de l'ordre des Mormyriformes [Osteology of the genera Mormyrus Linné, Mormyrops Müller, Hyperopisus Gill, Isichthys Gill, Myomyrus Boulenger, Stomatorhinus Boulenger and Gymnarchus Cuvier. General considerations on the systematics of the fishes of the order Mormyriformes]. Musée Royal de l'Afrique Centrale Tervuren, Belgique: Annales - Série in- $8^{\circ}-$ Sciences Zoologiques 200:1-194 +2 plates.

Toerring MJ, Serrier J. 1978. Influence of water temperature on the electric organ discharge (EOD) of the weakly electric fish Marcusenius cyprinoides (Mormyridae). J Exp Biol. $74: 133-150$. 
Werneyer M, Kramer B. 2002. Intraspecific agonistic interactions in freely swimming mormyrid fish, Marcusenius macrolepidotus (South African form). J Ethol. 20:107-121.

Werneyer M, Kramer B. 2005. Electric signalling and reproductive behaviour in a mormyrid fish, the bulldog Marcusenius macrolepidotus (South African form). J Ethol. 23:113-125.

Werneyer M, Kramer B. 2006. Ontogenetic development of electric organ discharges in a mormyrid fish, the bulldog Marcusenius macrolepidotus (South African form). J Fish Biol. 69:1-12. 